\title{
Timing of granite emplacement and cooling in the Songpan-Garzê Fold Belt (eastern Tibetan Plateau) with tectonic implications
}

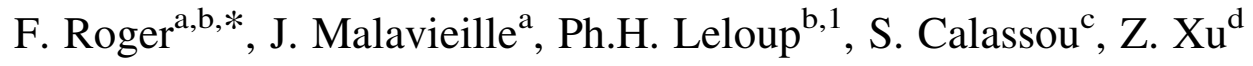 \\ ${ }^{a}$ Laboratoire Dynamique de la Lithosphère CNRS (UMR 5573), Université Montpellier II, 34095 Montpellier cedex 5, France \\ ${ }^{\mathrm{b}}$ Laboratoire de Tectonique, CNRS UMR 7578, IPG-Paris, 4 place Jussieu, 75252 Paris cedex 5, France \\ ${ }^{\mathrm{c}}$ Total-Fina-Elf, Pau, France \\ ${ }^{\mathrm{d}}$ Institute of Geology, Baiwangzhuang road, 100037 Beijing, People's Republic of China
}

Received 4 June 2002; revised 22 January 2003; accepted 23 January 2003

\begin{abstract}
$\mathrm{New} \mathrm{U}-\mathrm{Pb}$ and $\mathrm{Rb}-\mathrm{Sr}$ geochronology on syn- and post-orogenic granites provide constraints on the timing of major tectonic events in the Songpan-Garzê fold belt, west Sichuan, China. The Ma Nai granite was probably syn-kinematic with the main deformation and yields an age of $197 \pm 6 \mathrm{Ma}$ that is interpreted as an upper age limit of the Indosinian event. Zircons and apatites from the post-kinematic Rilonguan granite also yield Jurassic ages (195 \pm 6 and $181 \pm 4$ Ma). The post-orogenic Markam massif gives two ages of $188 \pm 1$ and $153 \pm 3$ Ma. Both granites are undeformed and cut structures in the Triassic sedimentary rocks. These results demonstrate that the major deformation and décollement tectonics in the Songpan-Garzê fold belt occurred prior to the Early Jurassic. The wide range of ages obtained for postkinematic granites (from Early Jurassic to Late Jurassic) suggests that, locally, magmatic activity persisted for a long time (at least $50 \mathrm{Ma}$ ) after the Indosinian compressional tectonism. No Tertiary ages have been obtained, suggesting that these granites were not affected strongly by the India-Asia collision.

(c) 2003 Elsevier Ltd. All rights reserved.
\end{abstract}

Keywords: Indosinian orogeny; Geochronology; Isotopic geochemistry; Granites; Décollement; Songpan-Garzê

\section{Introduction}

Eastern Tibet is one of the key areas for understanding the tectonic evolution of the Eurasian plate. There, in the Songpan-Garzê fold belt, great volumes $\left(\approx 5 \times 10^{6} \mathrm{~km}^{3}\right)$ of folded Triassic sediments have witnessed a complex tectonic history due to the interactions of three major continental Plate (North China, South China, Qiangtang) during closure of the Palaeo-Tethys in the Late Triassic (Fig. 1(a)). It is generally assumed that at least two major orogenic events occurred in the Songpan-Garzê Belt since Mesozoic time: a late-Triassic compressional event (Indosinian orogeny) and Tertiary deformation related to

\footnotetext{
* Corresponding author. Address: Laboratoire Dynamique de la Lithosphère CNRS (UMR 5573), Université Montpellier II, 34095 Montpellier cedex 5, France. Tel.: +334-67-14-33-96; fax: +334-67-5239-08.

E-mail address: francoise.roger@dstu.univ-montp2.fr (F. Roger)

1 Present address: Laboratoire de dynamique de la lithosphère, UMR 5570, 2 rue R. Dubois, 69622 Villeurbanne, France.
}

the India-Asia collision (Mattauer et al., 1992; Burchfield et al., 1995; Chen et al., 1995; Arne et al., 1997). Most workers propose that the Indosinian deformation was achieved by the end of the Triassic. This assertion is based on local stratigraphic observations, and the occurrence of widespread granitic magmatism, interpreted as post-orogenic, showing a very wide range of Mesozoic KAr ages starting at $200 \mathrm{Ma}$ (Geological Map of Qinghai-Xizang (Tibet) Plateau and adjacent Areas, 1991). However, the Jurassic age of the detrital sediments sealing the main folding event is uncertain and the geodynamic significance of the Mesozoic magmatism is poorly known. Most $\mathrm{K}-\mathrm{Ar}$ ages lack basic analytical and/or geological presentation making their interpretation dubious. For example, the occurrence of a Yanshanian (Jurassic-Cretaceous) orogenic phase is sometimes invoked to account for the wide scattering of the ages (Dirks et al., 1994; Chen et al., 1995; Arne et al., 1997).

A careful work on the geochronology of the SongpanGarzê plutonic rocks in the structural context (some of 


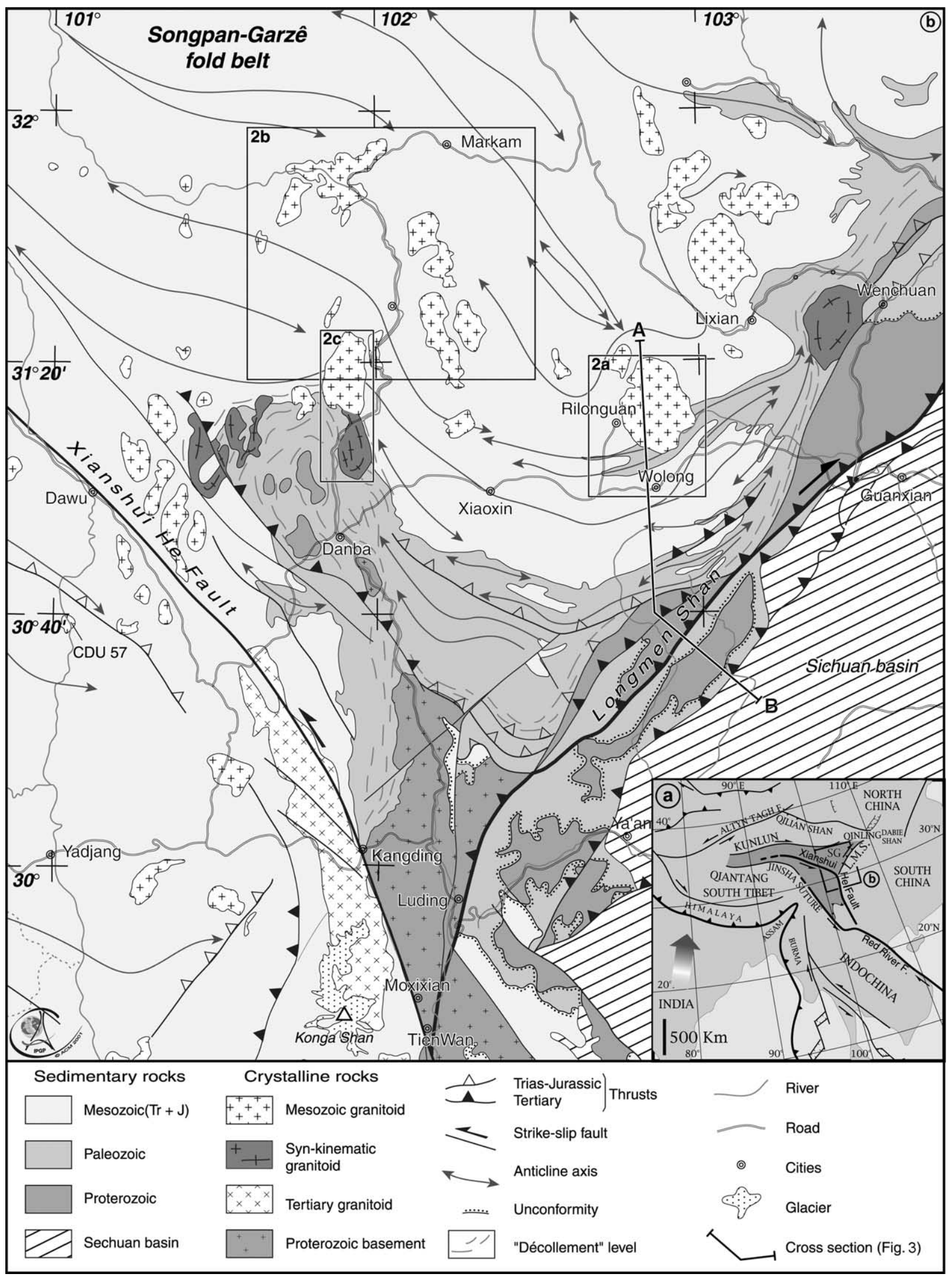

Fig. 1. (a) Location of the Songpan-Garzê fold belt (SG, dark grey) within continental Asia. LMS = Longmen Shan (b) Structural map of the southeastern part of the Songpan-Garzê fold belt. Note the different kinds of granites and their structural relationship (post- or syn-kinematic) with respect to the large-scale décollement and folds. Drawn after the 1/1000000 scale Geologic Map of Sichuan (1981). A and B are the end points of Fig. 3 cross-section. 
the plutons are deformed while others are late- to posttectonic relative to the Indosinian deformation event) is still needed, not only to better constrain the timing and extent of the Indosinian deformations but also that of later deformations.

\section{Geological setting}

The Songpan-Garzê fold belt is located in the eastern part of the Tibetan Plateau and west of the Sichuan basin. It is bounded by the South China, North China, North Tibet (Qiangtang), and South Tibet continental blocks (Fig. 1(a)). To the east, the Longmen-Shan thrustnappe belt separates the Songpan-Garzê fold belt from the Sichuan basin (Zhang et al., 1984; Chen et al., 1995; Chen and Wilson, 1996) (Fig. 1(b)). The western limit of the belt is marked by the Jinsha suture zone which is considered as a Late Palaeozoic subduction zone dipping either to the west (Sengör, 1985), or the east (Calassou, 1994). To the north, the Songpan-Garzê Triassic domain is bounded by the Qinling and Kunlun Mountains (Fig. 1(a)).

The Songpan-Garzê fold belt was mainly formed during the so-called Indosinian (Late Triassic) compressional tectonism, by shortening of a wide basin (Xu et al., 1992) filled with a thick $(5-15 \mathrm{~km})$ sequence of Triassic flyschoid sediments (Zou et al., 1984; Sengör, 1985; Rao and Xu, 1987; Mattauer et al., 1992; Nie et al., 1994). The shortening resulted from the convergence between the North China, and both the South China (e.g. Enkin et al., 1992) and the Qiangtang blocks (Roger et al., 2003). On the South China block, the Triassic series unconformably overlay the thick Paleozoic cover of the Yangtze craton that itself lies on upper Proterozoic (Sinian) sediments. The Sinian in turn unconformably overlie the old basement of the craton that has been dated at $0.8-1 \mathrm{Ga}$ by $\mathrm{U} / \mathrm{Pb}$ on zircons (Geological Map of Qinghai-Xizang Plateau and adjacent area, 1991; Luo and Long, 1992) (Fig. 1(b)). In the Songpan-Garzê, area the Triassic series are intensively folded and are separated from the crystalline basement outcropping near Danba by a large-scale décollement affecting the Paleozoic series (Malavieille et al., 1991; Calassou, 1994) (Fig. 1(b)). This crystalline basement shares many similarities with the basement of the Yangtze Craton outcropping farther south (Fig. 1(b)) and has been dated at $825 \pm 6 \mathrm{Ma}$ (U/Pb zircons age; Roger and Calassou, 1997). To the north, below the Triassic sediments, the exact nature (oceanic or continental) of the basement remains unknown.

A large-scale Songpan Garzê décollement has been recognized over more than $300 \mathrm{~km}$ and studied in detail in Tien Wan (SW of Konga Shan) and Danba areas (Mattauer et al., 1992; Xu et al., 1992; Calassou, 1994) (Fig. 1(b)). In the upper part of the sedimentary cover, major deformation is characterized by folds with vertical axial planes and schistosity bearing a vertical stretching lineation implying horizontal shortening (Calassou, 1994). The fold axes are continuous for several tens of kilometers and can easily be mapped (Figs. 1(b) and 2). Some of these folds are clearly crosscut by granitic plutons (Figs. 1(b) and 2). At depth a thick ductile décollement zone setting in the DevonianSilurian slates is characterized by a flat lying foliation bearing a north-south stretching lineation, 'a' type folds (with axes parallel to the lineation) and sheath folds. Shear criteria in the décollement suggest a large-scale southward thrusting of sediment sequences (Fig. 3) (Calassou, 1994). A high temperature-medium pressure metamorphism (garnet-sillimanite-kyanite), with $\mathrm{P}-\mathrm{T}$ conditions estimated at 5-6 kbar and $400-600{ }^{\circ} \mathrm{C}$ (Xu et al., 1992) is associated with this deformation. The corresponding depth $(\sim 20 \mathrm{~km})$ suggests that the Triassic series have been thickened by folding above the décollement. The total shortening has been estimated to be about $200 \mathrm{~km}$ (Mattauer et al., 1992; Calassou, 1994). Below the sedimentary cover, the basement is composed of granodiorites and adamelites intruded by basaltic dikes of probable Late Permian age (Roger and Calassou, 1997). Locally this basement is migmatized and affected by ductile deformations compatible with those of the décollement (Calassou, 1994).

The Triassic Songpan-Garzê fold belt has been affected by later deformations. In the Danba area, the large-scale décollement is affected by a large antiform with a NNW-SSE axis (Fig. 1(b)). The décollement level has also been exhumed in the hanging wall of the NE-SW faults of the LongmenShan belt that mark the transition from the Tibetan plateau to the Sichuan basin (Figs. 1(b) and 3). These faults have episodically absorbed significant shortening from the Late Triassic to present (Chen and Wilson, 1996). Toward the SW, the most prominent tectonic feature is the active Xianshui He fault (Allen et al., 1991), which is a sinistral strike slip fault. The fault zone is marked by a ductile shearing which affects the Konga Shan granitic pluton (Fig. 1(b)). Geochronological data on syn-kinematic granites have shown that the fault is active since at least the Miocene (13 Ma, $\mathrm{U}-\mathrm{Pb}$ on zircons) (Roger et al., 1995). The Xianshui He fault truncates the décollement level near Kanding (Fig. 1(b)).

The Songpan-Garzê area is marked by widespread magmatism characterized by three main groups of granitic rocks (Geological Map of Qinghai-Xizang Plateau and adjacent area, 1991; Liu, 1984; Yuan et al., 1991; Zhang et al., 1990; Xu et al., 1992).

1. Amphibole granite, two micas granite, and pegmatite granitoids that are typically related to late- to postorogenic Indosinian magmatism. Some of these granitoid bodies are deformed within the décollement level, while most of them clearly crosscut the folds affecting the Triassic cover and, locally the décollement itself (Fig. 1(b)). Geochronological data reported on geologic maps give ages ranging from 78 to $200 \mathrm{Ma}$ (Fig. 2(a)-(c)) (Geological Map of Qinghai-Xizang Plateau and Adjacent Area, 1991). 

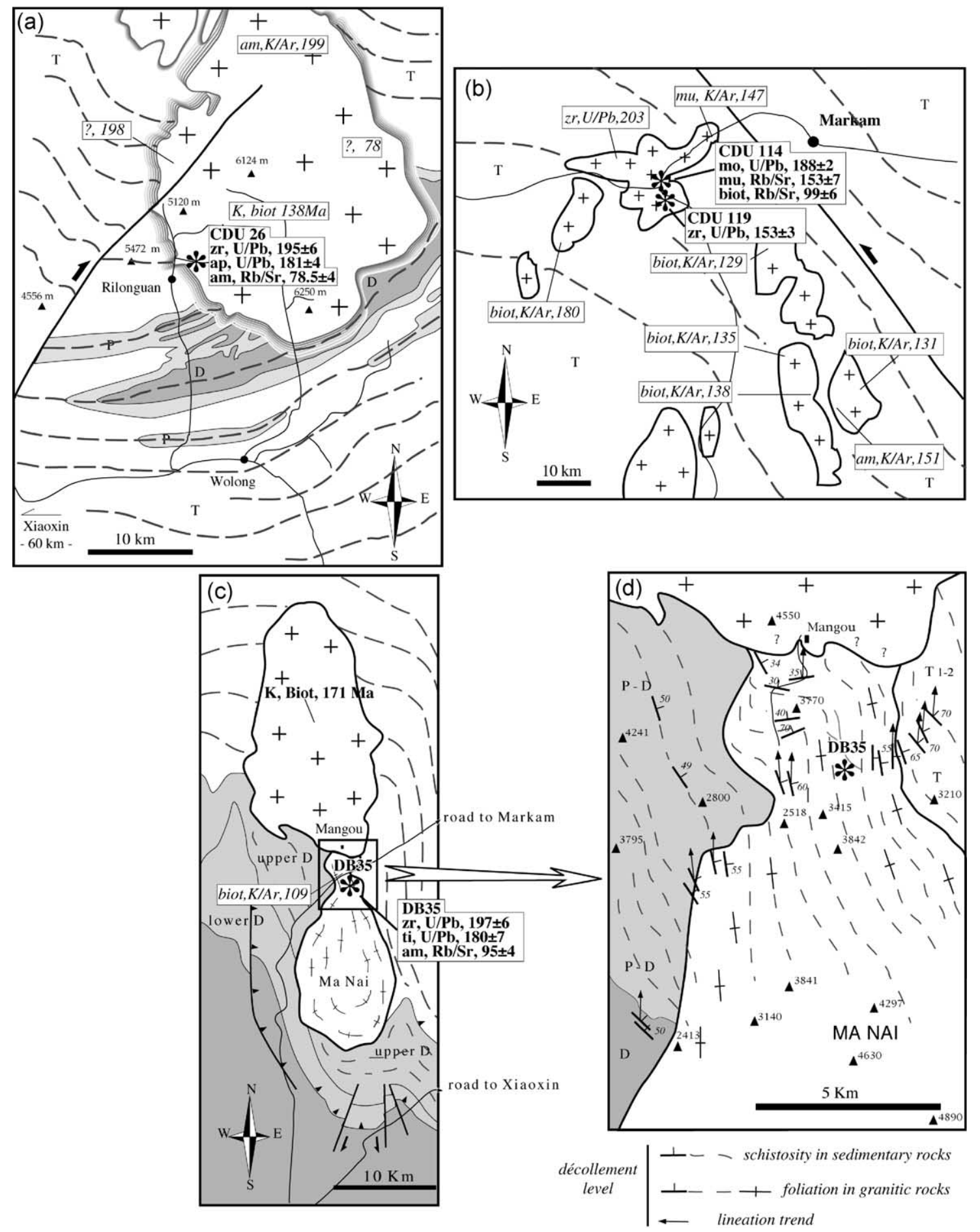

Fig. 2. Simplified structural maps of the dated granites. (a) Post-folding Rilonguan granite. (b) Post-folding Markam granite. (c) and (d) Syn-décollement Ma Nai granite. $\mathrm{D}=$ Devonian, $\mathrm{P}=$ Permian, $\mathrm{T}=$ Triassic. Dotted lines: trend of major folds in the Triassic series. Previous geochronological data indicated in italics give ages ranging from 78 to $200 \mathrm{Ma}$ (Geological Map of Qinghai-Xizang Plateau and Adjacent Area, 1981). Results of this study are in bold. Minerals: zr, zircon; mo, monazite; ap, apatite; ti, titanite; am, amphibole; mu, muscovite; biot, biotite. Ages in Ma. Fig. 2(d) present a close view of Fig. 2(c) showing the tectonic features (foliations and lineations) observed in the syn-kinematic Ma Nai granite and surrounding deformed series.

2. Large calc-alkaline plutons intrude the Triassic flysch in the Litang zone at the SW boundary of the SongpanGarzê belt. They are probably related to the magmatic arc interpreted by Mattauer et al. (1992) to indicate an east-northeast dipping subduction zone. $\mathrm{K}-\mathrm{Ar}$ data obtained by Chinese workers suggest $<$ NBsp emplacement around $200 \mathrm{Ma}$ (Geological Map of Qinghai-Xizang Plateau and Adjacent Area, 1991). 


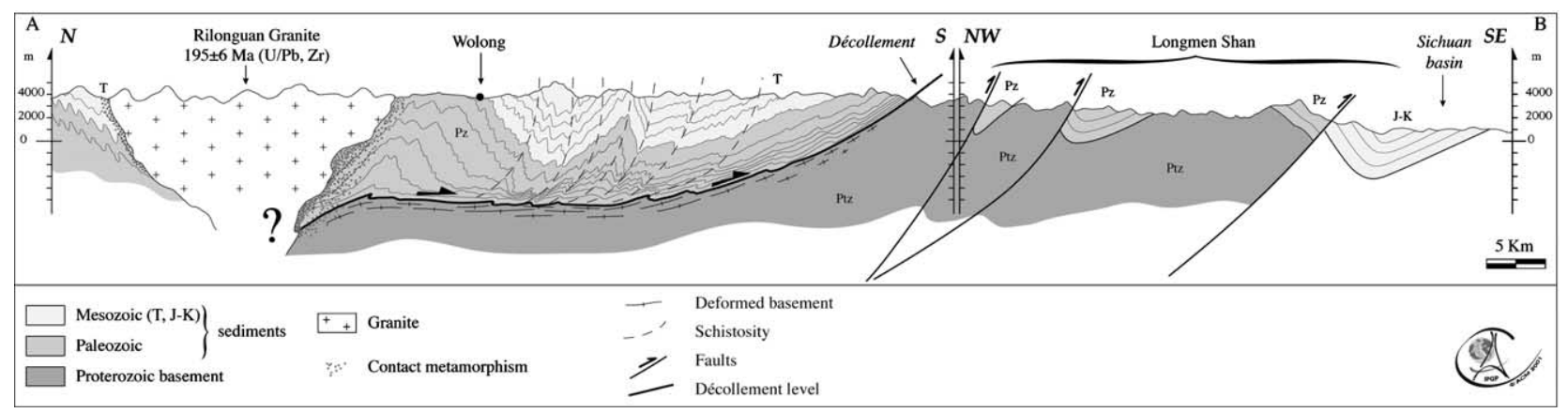

Fig. 3. Simplified cross-section of the Rilonguan granite and the Longmen Shan thrust belt. The section line A-B is located on Fig. 1. Drawn from the Geological Map of Qinghai-Xizang Plateau and Adjacent Area (1981); Calassou (1994).

3. Many granitic plutons aligned along the Xianshui He fault zone, previously considered as Mesozoic intrusions, are in fact related to Tertiary intracontinental strike-slip deformation (Roger et al., 1995) (Fig. 1(b)).

The aim of this study is to provide constrains on the tectonic history of the South-East Songpan-Garzê region. For this purpose, we present below the geological setting, the geochemical characteristics and the geochronology ( $\mathrm{U}-\mathrm{Pb}$ on accessory minerals as well as $\mathrm{Rb}-\mathrm{Sr}$ internal isochrons) of three granites from the first group.

\section{Results}

\subsection{Geochronology of the Rilonguan granite (CDU26)}

In the eastern part of the Songpan-Garzê area, close to the Wolong Panda Nature Reserve, outcrops the Rilonguan granitic massif, culminating at $6300 \mathrm{~m}$. This granite crosscuts a large-scale anticline with a core of Devonian rocks and Triassic sediments (Figs. 1(b), 2(a), and 3) and develops a contact metamorphic aureole with hornfels at its border (Figs. 2(a) and 3).

The analysed sample, CDU26, is taken from an undeformed coarse-grained amphibole granite. Its mineral composition is quartz $(15 \%)$, microcline $(35 \%)$, plagioclase (oligoclase) (20\%) and green hornblende (30\%). Accessory minerals are zircon, titanite, apatite and oxides.

Zircons are pink to purple and mostly euhedral; a typological study (Fig. 4(a)) reveals a homogeneous population, mostly of $\mathrm{P}_{4}-\mathrm{P}_{5}$ types, a pattern usually found in alkaline and hyperalkaline granites (Pupin, 1980). No inherited cores were observed. Apatites are clear euhedral crystals.

Five zircon fractions, ranging in weight from 0.77 to $1.58 \mathrm{mg}$, and three apatite fractions (about $2 \mathrm{mg}$ ) were analysed by the $\mathrm{U}-\mathrm{Pb}$ method (Table 1). For minerals younger than about $200 \mathrm{Ma}$, analysis of several zircon fractions is required to determine the real crystallization age. In fact, the concordance does not imply that the age obtained is geologically meaningful because the $\mathrm{Pb}$ loss trajectories and inheritance patterns both overlap with the concordia curve (Schärer et al., 1995; Roger, 1994). Plotted on a concordia diagram, the zircon points of CDU26 are concordant or sub-concordant, between 150 and $195 \mathrm{Ma}$ (Fig. 5(a)). All zircon fractions have similar ${ }^{207} \mathrm{~Pb} /{ }^{206} \mathrm{~Pb}$ ages $($ mean $=195 \pm 6 \mathrm{Ma}$ ) (Table 1; Fig. 5(a)), they are free of inherited components and show recent lead loss. We interpret this age $(195 \pm 6 \mathrm{Ma})$ as a crystallization age.

The apatite analyses overlap almost perfectly with each other in a concordant position around $180 \mathrm{Ma}$ (Fig. 5(b)). When treating with accessory minerals with low radiogenic lead contents (apatite, epidote, titanite) in concordant or subconcordant position, the $\mathrm{R}_{8}\left({ }^{206} \mathrm{~Pb} /{ }^{238} \mathrm{U}\right)$ apparent age is generally considered as the most reliable, because it is the least sensitive to common lead contamination (Mattinson, 1978). In the case of CDU26, the $\mathrm{R}_{8}$ apatite ages are homogeneous and yield a mean date of $181 \pm 4$ Ma (Table 1; Fig. 5(b)).

We also analysed a whole rock fraction, along with feldspar and amphibole fractions using the $\mathrm{Rb}-\mathrm{Sr}$ method (Table 2). It resulted in an array on the ${ }^{87} \mathrm{Rb} /{ }^{86} \mathrm{Sr}$ versus ${ }^{87} \mathrm{Sr} /{ }^{86} \mathrm{Sr}$ diagram, yielding a date of $78.5 \pm 4 \mathrm{Ma}$ $(\mathrm{MSWD}=1.7)$ and an initial ${ }^{87} \mathrm{Sr} /{ }^{86} \mathrm{Sr}$ of $0.7058 \pm 1$ (Fig. 5(c)).

\subsection{Geochronology of the Markam granite (CDU114 and CDU119)}

This is the northernmost granite body studied and is located about one hundred kilometers northwest of the Rilonguan massif (Fig. 1). Similar to the Rilonguan granite, it crosscuts the major folds, indicating a post-folding emplacement (Fig. 2(b)). Two different facies have been observed a few tens of meters apart: a porphyritic granite (CDU119) and a leucogranite (CDU114). Pegmatites with pluricentimetric tourmaline crystals and biotite-rich enclaves are associated with the leucogranite that could be an indication of a position close to the top of the pluton. The relationship between the porphyritic granite and the leucogranite could not be observed in the field.

CDU119 is taken from an undeformed coarse-grained granite, with feldspar phenocrystals. Its mineralogical 


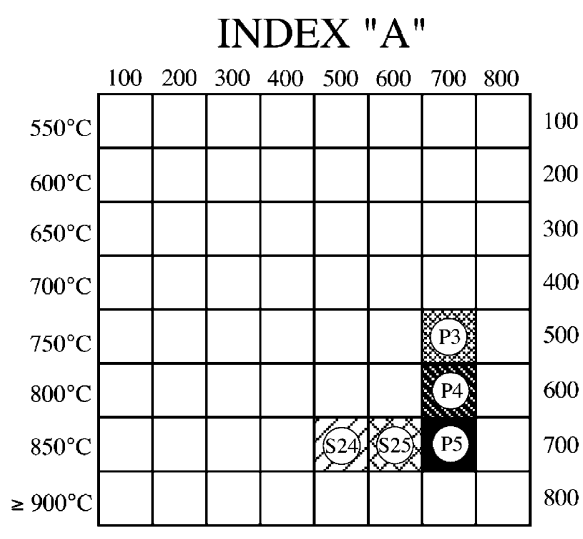

CDU 26

(a) RILONGUANUNDEFORMED GRANITE

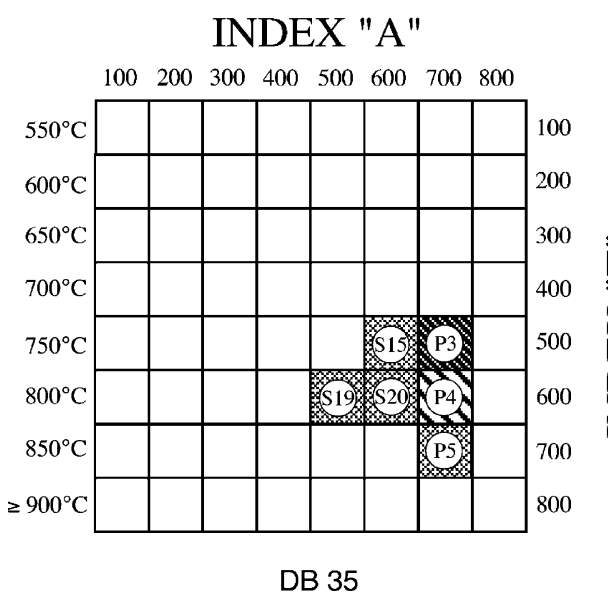

(c) MA NAI DEFORMED GRANITE

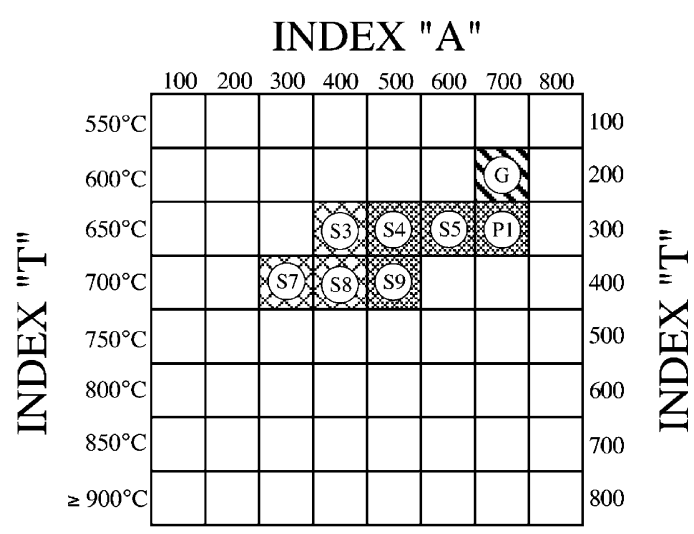

CDU 119

(b) MARKAM UNDEFORMED PORPHYRITIC GRANITE

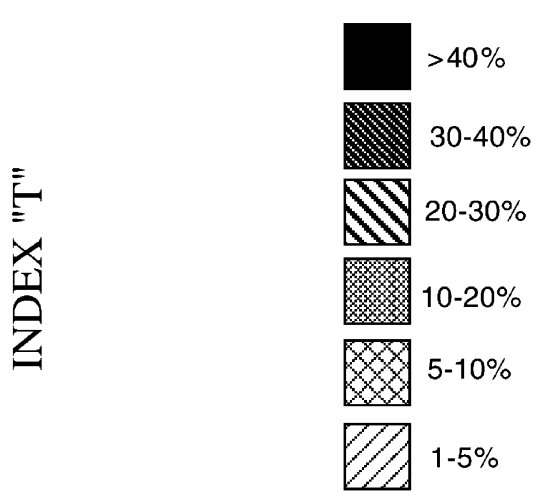

Fig. 4. Typological diagram of zircon from the Rilonguan granite (a), Markam granite (b) and Ma Nai granite (c). The 'A index' corresponds to the relative development of the (211) and (101) pyramids while the ' $\mathrm{T}$ index' corresponds to the relative development of the (100) and (110) prisms. 'A' and ' $\mathrm{T}$ ' indexes are correlated with the aluminium/alkali ratio and the temperature of the crystallization of granite, respectively (Pupin, 1980). The percentage of population corresponding to each morphology is indicated by various types of shading.

composition is quartz $(40 \%)$, microcline $(40 \%)$, plagioclase (oligoclase) $(10 \%)$ and biotite $(10 \%)$; accessory minerals are zircon and oxides. Zircons from this sample are euhedral and pinkish, with several cores and overgrowths. $90 \%$ of the grains were indexable, resulting in a typological distribution characteristic of differentiated calk-alkaline granite as indicated by the abundance of G-type grains (Pupin, 1980) (Fig. 4(b)).

For $\mathrm{U}-\mathrm{Pb}$ analysis, nine zircon fractions were handpicked according to grain size, morphology (euhedral or rounded) and typology ( $\mathrm{S}$ or $\mathrm{P}$ ) (Table 1). Plotted in a concordia diagram, no array can be drawn because the analysed fractions are scattered (Z's on Fig. 5(d)). The rounded zircon fractions contain the highest inherited component, with apparent ${ }^{207} \mathrm{~Pb} /{ }^{206} \mathrm{~Pb}$ dates up to $600 \mathrm{Ma}$. The most concordant fraction is constituted of about ten fine-grains $(<80 \mu \mathrm{m})$, G-type zircon grains, and defines a date of
$153 \pm 3 \mathrm{Ma}$. Such concordant G-type zircons were probably crystallized during the last magmatic stage (Pupin, 1980). They are thus most likely to be devoid of any inherited component especially when they are of very small size.

Six single zircon grains, selected to represent the different types observed following the typological study were analysed (Table 1, SZ's on Fig. 5(d)). Grains of $\mathrm{P}_{1}$ and $\mathrm{G}$ types give concordant to sub-concordant points (except one), while S-type grains contain some inherited lead. However, the most concordant single zircon is an $S_{5}$ grain that yields an age of $152 \pm 2 \mathrm{Ma}$.

In this sample (CDU119) the scattering in the concordia diagram is interpreted to result from the combination of an inherited component and $\mathrm{Pb}$ loss. The granite crystallization age most probably corresponds to the age of the most concordant zircons $(153 \pm 3$ for fraction and $152 \pm 2$ for the single zircon). 
Table 1

$\mathrm{U}-\mathrm{Pb}$ analytical results for zircon, monazite, titanite and apatite from the CDU26, CDU114, CDU119 and DB35 samples

\begin{tabular}{|c|c|c|c|c|c|c|c|c|c|}
\hline \multirow[t]{2}{*}{ Samples $^{\mathrm{a}}$} & \multirow[t]{2}{*}{$\begin{array}{l}\text { Weight } \\
(\mathrm{mg})\end{array}$} & $\begin{array}{l}\text { Concentrations } \\
(\mathrm{ppm})\end{array}$ & \multirow[t]{2}{*}{$\begin{array}{l}{ }^{206} \mathrm{~Pb} /{ }^{204} \mathrm{~Pb} \\
\text { measured }\end{array}$} & \multicolumn{3}{|c|}{ Atomic ratios ${ }^{\mathrm{b}}$} & \multicolumn{3}{|c|}{ Apparent ages $(\mathrm{Ma})^{\mathrm{b}}$} \\
\hline & & $\mathrm{Pb}$ & & ${ }^{206} \mathrm{~Pb}^{*} /{ }^{238} \mathrm{U}$ & ${ }^{207} \mathrm{~Pb}^{*} /{ }^{235} \mathrm{U}$ & ${ }^{207} \mathrm{~Pb}^{*} /{ }^{206} \mathrm{~Pb}^{*}$ & ${ }^{206} \mathrm{~Pb}^{*} /{ }^{238} \mathrm{U}$ & ${ }^{207} \mathrm{~Pb}^{*} /{ }^{235} \mathrm{U}$ & ${ }^{207} \mathrm{~Pb}^{*} /{ }^{206} \mathrm{~Pb}^{*}$ \\
\hline
\end{tabular}

Rilonguan undeformed granite (CDU 26)

Zircons

1-Large, pink

2-Meduim, pink

1.28

3-Medium, pink

1.28
0.77
1.16

4-Medium, pink

5-Small, pink

1.02

$\begin{array}{lrr}567 & 14.9 & 1520 \\ 517 & 13.1 & 404 \\ 428 & 11.9 & 535 \\ 541 & 16.5 & 1418 \\ 709 & 23.2 & 1685\end{array}$

Apatites

6-Large

8-Medium

$\begin{array}{ll}2.06 & 190 \\ 1.8 & 115 \\ 1.96 & 122\end{array}$

6.2
3.7
4.1

41.2

41.2
47.8

44.5

0.02332

0.02592

0.1604

$0.02808 \quad 0.1933$

0.03011

0.2073

0.04988

0.04981
0.04992

0.04994

$153 \pm 2$

$149 \pm 2$

$165 \pm 2$

$178 \pm 2$

$156 \pm 2$

$151 \pm 2$

$166 \pm 2$

$195 \pm 15$

$0.0283 \quad 0.182$

0.0285

0.182

$192 \pm 2$

$191 \pm 2$

$186 \pm 15$

Markam undeformed porphyritic granite (CDU 119)

Fractions of zircons

9-Large, rounded, pink

10-Large, rounded, pink

11-Medium, rounded, pink

$\begin{array}{ll}0.31 & 3308 \\ 0.07 & 3305 \\ 0.62 & 2321 \\ 0.34 & 3058 \\ 0.33 & 3081 \\ 0.18 & 3401 \\ 0.36 & 1848 \\ 0.45 & 4386 \\ - & -\end{array}$

$124 \quad 869$

12-Medium, type P, pink

112

3-Medium, type S, pink

14-Small, type P, pink

15-Small, type S, pink

16-Small, type S, pink

17-Very small, G1, pink

$-\quad 610$

\section{9}

1150
3472

1028

1592

1240

1746

1972
610

Single zircons

18-Type P1, pink

19-Type S4, pink

20-Type S8, pink

21-Type G1, pink

$0.014 \quad 3123 \quad 44$

656

$\begin{array}{rr}0.019 & 3123 \\ 0.010 & 505\end{array}$

$\begin{array}{ll}0.010 & 1322\end{array}$

22-Type P1, pink

$\begin{array}{ll}0.009 & 1525\end{array}$

23-Type S5, pink

$0.013 \quad 1260$

13
39

40

727

578

581

828

801

0.03956
0.03527
0.04745
0.03450
0.03545
0.02624
0.03658
0.02459
0.02426

0.046

0.048

$180 \pm 5$

$181+5$

$181 \pm 4$

$170 \pm 18$

$177 \pm 18$

$179 \pm 20$

Markam undeformed leucogranite (CDU 114)

Monazite

24-Yellow, transparent

500

634

$\begin{array}{lll}0.01518 & 0.1055 & 0.05044 \\ 0.02778 & 0.1969 & 0.05135 \\ 0.03069 & 0.2176 & 0.05143 \\ 0.02349 & 0.1549 & 0.04783 \\ 0.02206 & 0.1472 & 0.04839 \\ 0.02387 & 0.1615 & 0.04907\end{array}$

0.02951

0.2020

0.04964

$188 \pm 2$

$192 \pm 9$

Ma Nai deformed granite (DB 35)

Zircons

25-Large to medium, rounded

26-Large, colourless

0.50

27-Medium, colourless

$\begin{array}{rrrr}0.50 & 284 & 14 & 789 \\ 0.35 & 373 & 16 & 1090 \\ 0.15 & 544 & 20 & 659\end{array}$

789
1090
659

0.04451

0.3262

$0.04048 \quad 0.2928$

0.2311

0.05316
0.05246
0.05056

$280 \pm 1$
$256 \pm 3$

$256 \pm 3$
$210 \pm 3$

$\begin{array}{ll}287 \pm 2 & 336 \pm 4 \\ 261 \pm 2 & 305 \pm 4 \\ 211 \pm 3 & 221 \pm 5\end{array}$

$\begin{array}{ll}261 \pm 2 & 305 \pm 4 \\ 211 \pm 3 & 221 \pm 5\end{array}$

(continued on next page) 


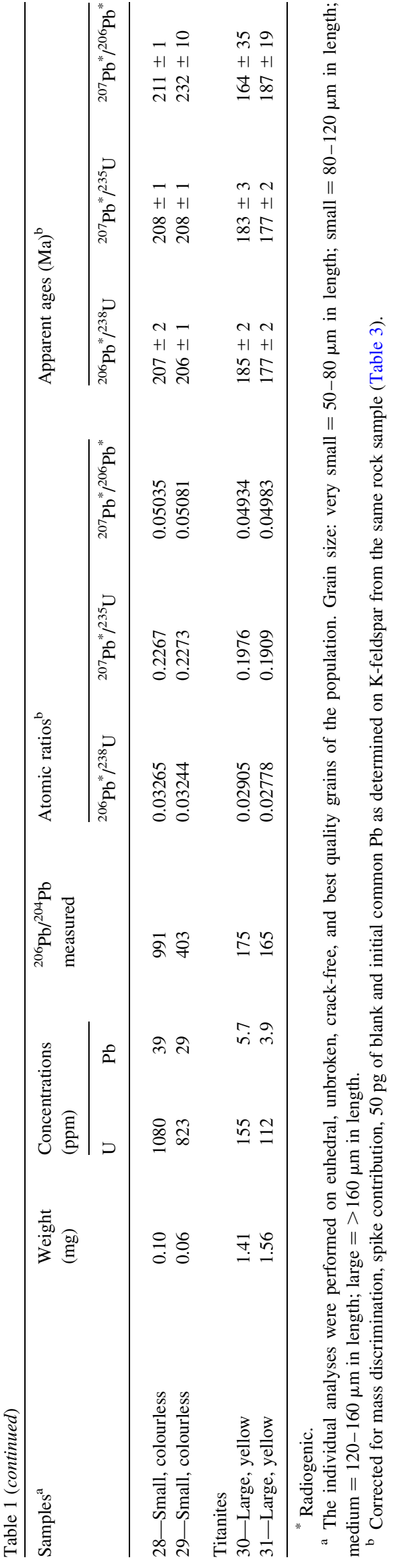

CDU114 is taken from an undeformed coarse-grained leucogranite. Its mineral composition is quartz (40\%), microcline $(40 \%)$, muscovite $(10 \%)$, plagioclase $(<5 \%)$ and biotite $(<5 \%)$. Accessory minerals are scarce: zircon, monazite and oxides.

One monazite fraction selected for $\mathrm{U}-\mathrm{Pb}$ analysis, of yellowish sub-euhedral grains, yields a concordant point in the concordia diagram, with a $\mathrm{R}_{8}$ date of $188 \pm 2 \mathrm{Ma}$ and a $\mathrm{R}_{5}$ date of $187 \pm 1 \mathrm{Ma}$ (Table 1; Fig. 5(e)). As discussed above, a single point may not be enough for precise dating of the Mesozoic rocks; however, we were unable to concentrate enough monazite grains for further analyses.

We also analysed whole rock, feldspar, biotite and muscovite fractions by the $\mathrm{Rb}-\mathrm{Sr}$ method (Table 2). Plotted in an isochron diagram, the four points defined two separate groups: whole rock, feldspar and muscovite give a date of $153 \pm 7 \mathrm{Ma}$ and an initial $\mathrm{Sr}$ ratio of $0.7245 \pm 12$ (MSWD $=0.01$ ), while the whole rock-feldspar-biotite array yielded a date of $99 \pm 6 \mathrm{Ma}$ and an initial Sr ratio of $0.7328 \pm 10($ MSWD $=1.4)($ Fig. $5(\mathrm{f}))$.

\subsection{Geochronology of the Ma Nai granite (DB35)}

DB35 is taken from a deformed amphibole granite (Fig. 2 (c)). Its mineralogical composition is quartz (15\%), microcline (20\%), plagioclase (andesine) (10\%) and green hornblende $(55 \%)$. Accessory minerals are zircon, titanite, apatite, pyrite and oxides. The granite is located on the Danba-Markam road, about 30 km NNE of Danba (Figs. 1 and 2(c)). This pluton outcrops within the décollement level between the Palaeozoic (western side) and Mesozoic series (eastern side). Regional foliation and stretching lineation have similar orientation patterns both in the country rocks and in the granite. Detailed structural analysis (Calassou, 1994) strongly suggest that the Ma Nai granite was synkinematic. Close to the contacts between the granite and the metamorphosed Triassic and Paleozoic rocks, the foliation is steeply dipping and contains a well developed subhorizontal north-south lineation. Shear criteria along such contacts are consistent with top to the south thrusting (Calassou, 1994). To the north, the Ma Nai granite and the main deformation structures are cartographically crosscut by a late, undeformed post-tectonic body (Mangou granite) (Fig. 2(c) and (d)).

Zircons from sample DB35 are transparent, colourless, and generally euhedral; one core has been observed. A typological analysis on about 50 grains revealed that about $60 \%$ of the zircons are indexable, while $25 \%$ are rounded. The indexable population is homogeneous, mostly $\mathrm{P}_{3}-\mathrm{P}_{4}$ grains, a pattern typical of alkaline granitoids (Fig. 5(c)). The analysed titanites are euhedral, golden brown crystals.

Five zircon fractions for $\mathrm{U}-\mathrm{Pb}$, ranging in weight from 0.06 to $0.5 \mathrm{mg}$, were analysed (Table 1). When plotted on a concordia diagram, the data define a reverse discordia, with a lower intercept at $197 \pm 6 \mathrm{Ma}$ and an upper intercept at $433 \pm 24 \mathrm{Ma}$ (Fig. 5(g)). The most 

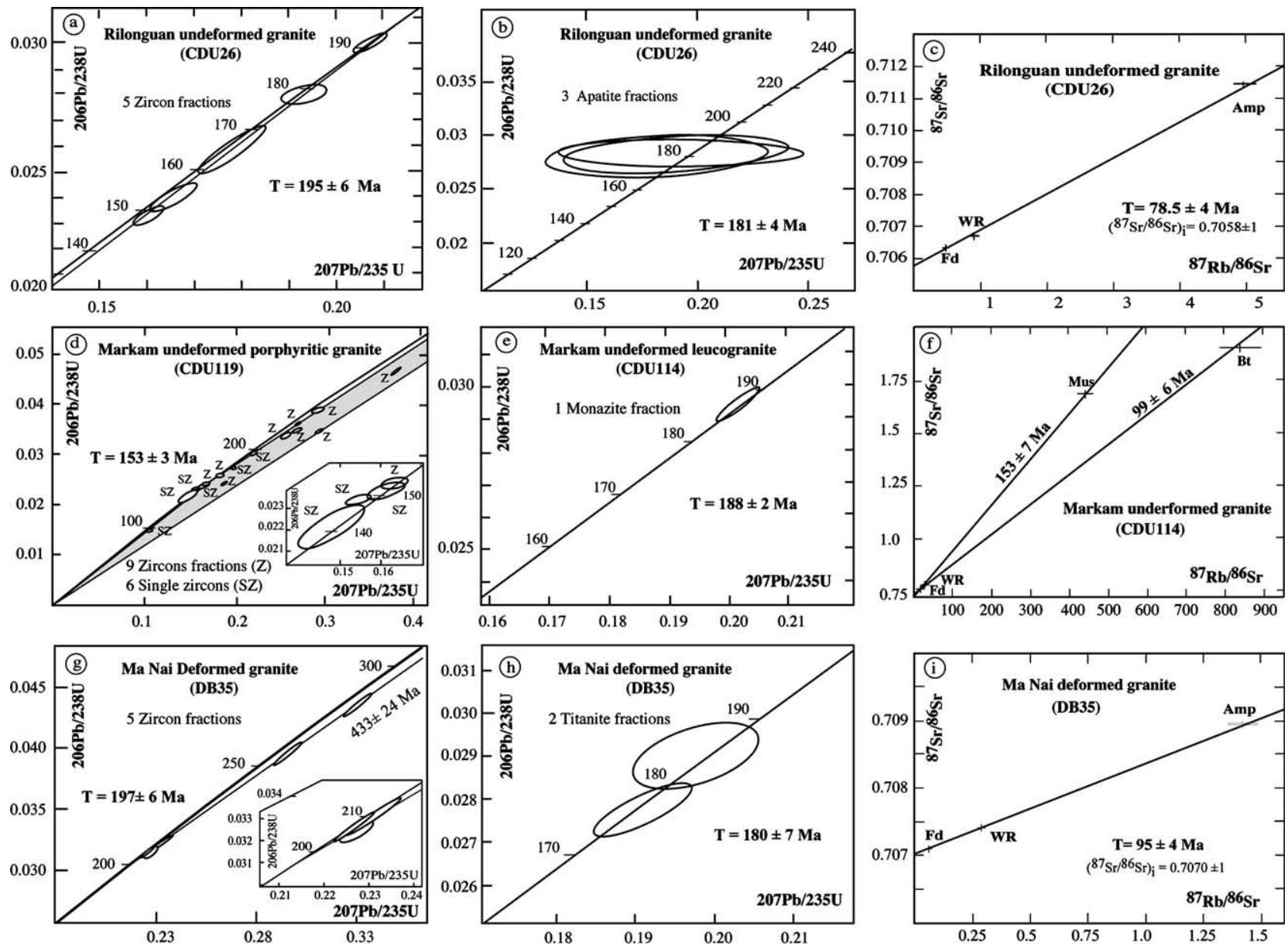

Fig. 5. Concordia and isochron diagrams of the dated minerals. Concordia diagram for apatite, titanite, monazite and zircon from the Rilonguan undeformed granite (CDU26) (a and b), Markam undeformed granite (CDU114 and CDU119) (d and e) and Ma Nai deformed granite (DB35) (g and h). Rb-Sr diagram of whole rock and minerals from granitoids: Rilonguan undeformed granite (CDU26) (c), Markam undeformed granite (CDU114) (f) and Ma Nai deformed granite (DB35) (i). Except the whole rock of CDU26 (c) and the amphibole of DB35 (i), the error in ${ }^{87} \mathrm{Sr} /{ }^{86} \mathrm{Sr}$ is smaller than indicated by the symbol. The error for initial $\mathrm{Sr}$ ratio is given on the last digit of the values caluled. WR: whole rock, Fd: feldspar, Bt: biotite, Mus: muscovite and Amp: amphibole.

discordant fraction corresponds to rounded grains, while fine euhedral zircon fractions are sub-concordant and have higher $\mathrm{U}$ and $\mathrm{Pb}$ contents, possibly indicating that small size grains crystallized during the last magmatic stages (Silver and Deutsch, 1961), incorporating very low amounts of inherited lead. The ages of these small size fractions (e.g. $208 \pm 1$ and $207 \pm 2 \mathrm{Ma}$ and $206 \pm 1 \mathrm{Ma}$ for the $R_{5}$ and $R_{8}$, respectively) are slightly older than the lower intercept age of $197 \pm 6 \mathrm{Ma}$. This rejuvenation of the lower intercept age can be due to a slight recent lead loss. The age of $197 \pm 6 \mathrm{Ma}$ should thus be interpreted as a minimum emplacement age.

Two titanite fractions were analysed and corrected from common lead, determined on a K-feldspar fraction (Table 3). Plotted on a concordia diagram, they give concordant points at $177 \pm 2$ and $184 \pm 3 \mathrm{Ma}$ (Fig. $5(\mathrm{~h})$ ).

$\mathrm{Rb}-\mathrm{Sr}$ data are reported in Table 2. The points representing whole rock, feldspar and amphibole define an
Table 2

$\mathrm{Rb}-\mathrm{Sr}$ analytical results for whole rock and minerals

\begin{tabular}{|c|c|c|c|c|}
\hline Samples & $\mathrm{Rb}(\mathrm{ppm})$ & $\mathrm{Sr}(\mathrm{ppm})$ & $\left({ }^{87} \mathrm{Rb} /{ }^{86} \mathrm{Sr}\right)$ & $\left({ }^{87} \mathrm{Sr} /{ }^{86} \mathrm{Sr}\right)( \pm$ \\
\hline \multicolumn{5}{|c|}{ Rilonguan granite CDU 26} \\
\hline Whole rock & 171 & 517 & 0.906 & $0.70675 \pm 2$ \\
\hline Feldspar & 181 & 1129 & 0.495 & $0.70637 \pm 2$ \\
\hline Amphibole & 172 & 99.5 & 5.001 & 0.71145 \\
\hline
\end{tabular}

Markam granite CDU 114

$\begin{array}{lrrcr}\text { Whole rock } & 425 & 63 & 19.45 & 0.76594 \pm 1 \\ \text { Feldspar } & 455 & 121 & 10.88 & 0.74811 \pm 1 \\ \text { Biotite } & 1345 & 5.2 & 842.5 & 1.90282 \pm 2 \\ \text { Muscovite } & 741 & 5.3 & 444 & 1.68823 \pm 2\end{array}$

Ma Nai granite DB 35

$\begin{array}{lllll}\text { Whole rock } & 71.5 & 704 & 0.294 & 0.70741 \pm 1\end{array}$

$\begin{array}{lllll}\text { Feldspar } & 40 & 1721 & 0.067 & 0.70712 \pm 1\end{array}$

$\begin{array}{lllll}\text { Amphibole } & 57 & 116 & 1.424 & 0.70897 \pm 1\end{array}$

a The maximum error for ${ }^{87} \mathrm{Rb} /{ }^{86} \mathrm{Sr}$ is $\pm 4 \%$, and for ${ }^{87} \mathrm{Sr} /{ }^{86} \mathrm{Sr}$, it is given on the last digit of the values measured.

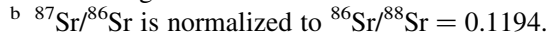


Table 3

$\mathrm{Pb}$ isotopic compositions of K-feldspar

\begin{tabular}{lllllr}
\hline Samples & ${ }^{206} \mathrm{~Pb} /{ }^{204} \mathrm{~Pb}^{\mathrm{a}}$ & ${ }^{207} \mathrm{~Pb} /{ }^{204} \mathrm{~Pb}^{\mathrm{a}}$ & ${ }^{208} \mathrm{~Pb} /{ }^{204} \mathrm{~Pb}^{\mathrm{a}}$ & $T^{\mathrm{b}}$ & $\mu_{2}{ }^{\mathrm{b}}$ \\
\hline CDU 26 & 18.431 & 15.740 & 39.016 & 426 & 10.30 \\
DB 35 & 18.376 & 15.665 & 38.797 & 309 & 9.95 \\
CDU 114 & 18.593 & 15.801 & 39.161 & 426 & 10.52 \\
CDU 119 & 18.630 & 15.781 & 38.891 & 363 & 10.42 \\
CDU 57 & 18.620 & 15.791 & 39.120 & 387 & 10.47 \\
\hline
\end{tabular}

${ }^{a}$ Corrected for mass discrimination. The maximum errors on atomic ratio are $\pm 0.2 \%$.

b $\mu_{2}$ and $T$ model age calculed after Stacey and Kramers model (1975).

array in the isochron diagram, with a date of $95 \pm$ $4 \mathrm{Ma}(\mathrm{MSWD}=0.22)$ and an initial $\mathrm{Sr}$ ratio of $0.7070 \pm 1$ (Fig. 5(i)).

\subsection{Isotopic geochemistry of the Songpan-Garzê granites}

The four granitoids have been analysed for $\mathrm{Pb}, \mathrm{Sr}$, and Nd to characterize their origin. A fifth sample (CDU57) was taken from a small leucogranitic body east of the Xianshui He fault zone, on the road from Dawu toYadjang (Fig. 1(b)). This granite is probably posterior to the main folding/ décollement event.

The results of $\mathrm{U} / \mathrm{Pb}$ analyses on feldspars are given in Table 3. The isotopic ratios are corrected from the mass discrimination (1.12 $\pm 0.3 \%$ o/a.m.u.) and from radiogenic $\mathrm{Pb}$ produced by disintegration of $\mathrm{U}$ since their emplacement (200 Ma). The initial isotopic compositions of these samples are between 18.37 and 18.63 for the ${ }^{206} \mathrm{~Pb} /{ }^{204} \mathrm{~Pb}$ ratios and between 15.66 and 15.80 for the ${ }^{207} \mathrm{~Pb} /{ }^{204} \mathrm{~Pb}$ ratios. The $\mu_{2}$ values $\left(\mu={ }^{208} \mathrm{U} /{ }^{204} \mathrm{~Pb}\right)$ and model ages $T$ are calculated from the two stages model of Stacey and Kramers (1975) (Table 3). $\mu_{2}$ are homogeneous with values ranging from 9.95 to 10.52 . The initial isotopic compositions of feldspars are plotted in the ${ }^{207} \mathrm{~Pb} /{ }^{204} \mathrm{~Pb}$ versus ${ }^{206} \mathrm{~Pb} /{ }^{204} \mathrm{~Pb}$ diagram where the upper crust evolution curve (U.C) has been drawn following the model of Zartman and Doe (1981) (Fig. 6). The actual and initial compositions of $\mathrm{Sr}$ and $\mathrm{Nd}$, as well as the concentrations of $\mathrm{Rb}, \mathrm{Sr}, \mathrm{Sm}$ and $\mathrm{Nd}$ of the whole rock of these granites are reported in Table 4. Analytical points of these five samples have been plotted in the initial $\epsilon \mathrm{Nd}$ versus age diagram (Fig. 7). On these diagrams, the Songpan-Garzê granites appear to define two groups with distinct mineralogy: group I corresponds to amphibole granites (CDU26 and DB35) while group II corresponds to granites containing micas (biotite and/or muscovite, CDU114, 119 and 57) (Table 5, Figs. 6 and 7). Initial isotopic compositions $\mathrm{Sr}$ and initial $\epsilon \mathrm{Nd}$ of these granites are heterogeneous, ranging from 0.704 to 0.712 and from -0.44 to -9.97 , respectively. However, for the granites with amphibole (group I), values for $\mathrm{Sr}$ (0.704-0.707) are radiogenically low and they have the lowest ${ }^{87} \mathrm{Rb} /{ }^{86} \mathrm{Sr}$ ratios $(<1)$. They are also characterized by the highest radiogenic values in $\mathrm{Nd}$, the lowest ${ }^{147} \mathrm{Sm} /{ }^{144} \mathrm{Nd}$ ratios $(<0.10)$ and model ages $T_{\mathrm{DM}}$ (depleted mantle) (DePaolo, 1981) around 800-900 Ma (Table 4). The granites containing micas (group II), are characterized by highly radiogenic Sr ratios (0.710-0.712), by the lowest radiogenic value in $\mathrm{Nd}$, and model ages around $1.8-1.6 \mathrm{Ga}$ (Table 4).

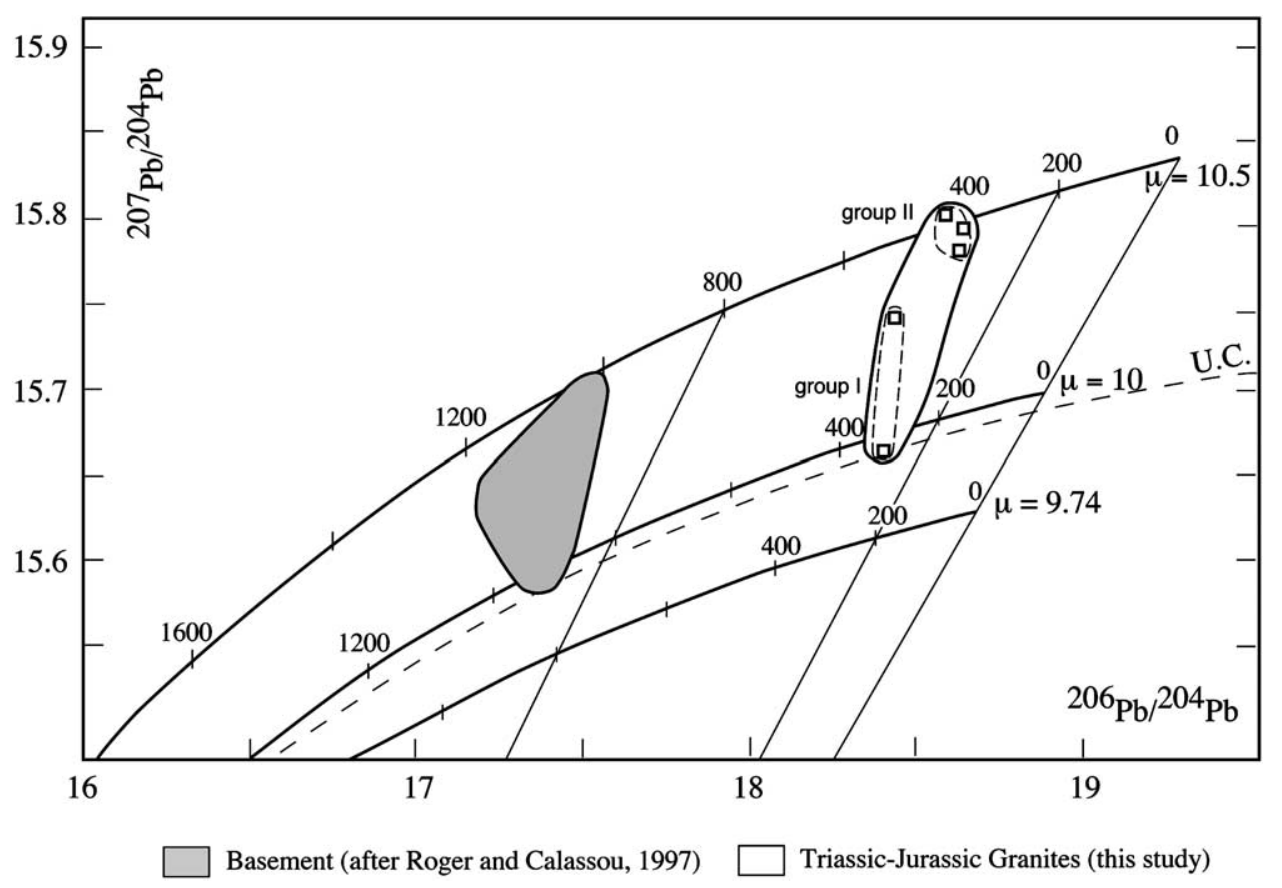

Fig. 6. The initial isotopic composition of K-feldspar in the ${ }^{207} \mathrm{~Pb} /{ }^{204} \mathrm{~Pb}$ versus ${ }^{206} \mathrm{~Pb} /{ }^{204} \mathrm{~Pb}$ diagram (Stacey and Kramers, 1975) of the studied granites. UC: upper crust evolution curve after Zartman and Doe (1981). 
Table 4

$\mathrm{Sm}-\mathrm{Nd}$ and $\mathrm{Rb}-\mathrm{Sr}$ isotopic data of whole rock

\begin{tabular}{|c|c|c|c|c|c|c|c|c|c|c|c|c|}
\hline Sample & $\begin{array}{l}\text { Sm } \\
(\mathrm{ppm})\end{array}$ & $\begin{array}{l}\mathrm{Nd} \\
(\mathrm{ppm})\end{array}$ & ${ }^{147} \mathrm{Sm} /{ }^{144} \mathrm{Nd}$ & ${ }^{143} \mathrm{Nd} /{ }^{144} \mathrm{Nd} \pm 2 \sigma$ & $\epsilon \mathrm{Nd}_{0}$ & $\epsilon \mathrm{Nd}_{\mathrm{T}}$ & $\begin{array}{l}T_{\mathrm{DM}} \\
(\mathrm{Ga})\end{array}$ & $\begin{array}{l}\mathrm{Rb} \\
(\mathrm{ppm})\end{array}$ & $\begin{array}{l}\mathrm{Sr} \\
(\mathrm{ppm})\end{array}$ & ${ }^{87} \mathrm{Rb} /{ }^{86} \mathrm{Sr}$ & ${ }^{87} \mathrm{Sr} /{ }^{86} \mathrm{Sr} \pm 2 \sigma$ & $\begin{array}{l}\left({ }^{87} \mathrm{Sr} /{ }^{86} \mathrm{Sr}\right) 200 \\
\mathrm{Ma}\end{array}$ \\
\hline CDU 26 & 10.2 & 53.4 & 0.0978 & $0.512492 \pm 3$ & -2.85 & -0.44 & 0.76 & 171 & 518 & 0.9575 & $0.70685 \pm 3$ & 0.7041 \\
\hline DB 35 & 6.6 & 37.5 & 0.0973 & $0.512381 \pm 25$ & -5.01 & -2.56 & 0.90 & 72 & 705 & 0.2936 & $0.70742 \pm 1$ & 0.7066 \\
\hline CDU 114 & 2.6 & 13.7 & 0.1253 & $0.512091 \pm 2$ & -10.67 & -8.93 & 1.65 & 425 & 63 & 19.46 & $0.76593 \pm 2$ & 0.7106 \\
\hline CDU 119 & 3.1 & 13 & 0.1329 & $0.512128 \pm 9$ & -9.95 & -8.40 & 1.68 & 127 & 116 & 3.157 & $0.72050 \pm 4$ & 0.7115 \\
\hline CDU 57 & 2.1 & 7.1 & 0.1301 & $0.512046 \pm 7$ & -11.55 & -9.97 & 1.79 & 159 & 27 & 15.79 & $0.74588 \pm 1$ & 0.7101 \\
\hline
\end{tabular}

\section{Discussion}

The two groups of granites probably correspond to distinct melting sources. For the amphibole granites group (group I), the relatively young $T_{\mathrm{DM}}$ and the moderately negative $\epsilon \mathrm{Nd}$ values (Table 5) suggest that these granites did not incorporate significant amounts of ancient (e.g. formed at $1.8 \mathrm{Ga}$ ) continental crust. For these granites we might envisage participation of a dominantly crustal ${ }^{147} \mathrm{Sm} /{ }^{144} \mathrm{Nd}$ ratio $(0.112)$, extracted $0.9-1.1 \mathrm{Ga}$ ago from a depleted mantle. The corresponding material would have an $\epsilon \mathrm{Nd}_{(0)}$ ranging between -2.1 and -4.7 , similar to the values found in our samples (DB35 and CDU26), and to that of the Songpan-Garzê and South China basements (Roger and Calassou, 1997) (Fig. 7). On the other hand, the $T_{\mathrm{DM}}$ and negative $\epsilon \mathrm{Nd}$ values of the mica granites group (group II) indicate that these granites have incorporated significant amounts of continental crustal material older than $1.6 \mathrm{Ga}$ (Tables 4 and 5, Fig. 7). Such material may be the Middle Triassic sandstones of the Songpan-Garzê fold belt that were mostly derived from Middle Proterozoic source rocks (1.8-2.0 Ga, Luliang crust) with minor contributions of Late Archean (2.5-2.6 Ga), Caledonian (400-450 Ma) and to a lesser degree, Sinian (ca. $760 \mathrm{Ma}$ ) and Permo-Triassic (230-260 Ma) material (Bruguier et al., 1997). In summary, Songpan-Garzê granites may have resulted from partial melting of the underlying crust: South China or SongpanGarzê Proterozoic basement for group I and Middle Triassic sediments for group II.

Geological interpretation of geochronological data must account for the closure temperature of each mineral/geochronological system (Dodson, 1973). In the following discussion, we have considered the $\mathrm{U} / \mathrm{Pb}$ closure temperatures listed in Table 6.

The $\mathrm{U} / \mathrm{Pb}$ zircon ages because of a very high closure temperature for $\mathrm{U} / \mathrm{Pb}$ system give thus the best estimate for the timing of granite emplacement. The $197 \pm 6 \mathrm{Ma}$ is a minimum emplacement age of the syn-kinematic Ma Nai granite (DB35, group I). The post kinematic granites were emplaced at $195 \pm 6 \mathrm{Ma}$ (Rilonguan, CDU26, group I) and $153 \pm 3 \mathrm{Ma}$ (Markam granite, porphyritic facies, CDU119, group II), respectively.

A monazite fraction from the leucocratic facies of the Markam granite (CDU114) gives a concordant point at
$188 \pm 2$ Ma. A single point is theoretically not enough to obtain a relyable age. Nevertheless, by comparison with the ages obtained on several other samples (CDU26, DB35), we interprete it as an emplacement age from the leucocratic facies of the Markam granite. This age is significantly older than the $153 \pm 3 \mathrm{Ma}$ age obtained on zircons for the emplacement of the porphyritic facies (CDU119). The relationship between the two facies is unclear, and the most probable interpretation is that the two facies of the Markam granite correspond in fact to two distinct intrusions.

In the Rilonguan and Ma Nai granites, the $\mathrm{U}-\mathrm{Pb}$ geochronology of apatite and titanite yields similar ages at about $180 \mathrm{Ma}$. These ages are younger than those from the zircons and are in good agreement with their lower closure temperature (Table 6). We interpret them as cooling ages, suggesting a cooling rate of about $10-20{ }^{\circ} \mathrm{C} / \mathrm{Ma}$ in the Rilonguan and Ma Nai granites during the Early Jurassic (curvela, Fig. 8).

Other methods can be used to constrain the granites cooling history at lower temperatures (Fig. 8). For example, the $\mathrm{Rb}-\mathrm{Sr}$ closure temperatures have been determined for biotite and muscovite, and range from 300 to $350{ }^{\circ} \mathrm{C}$

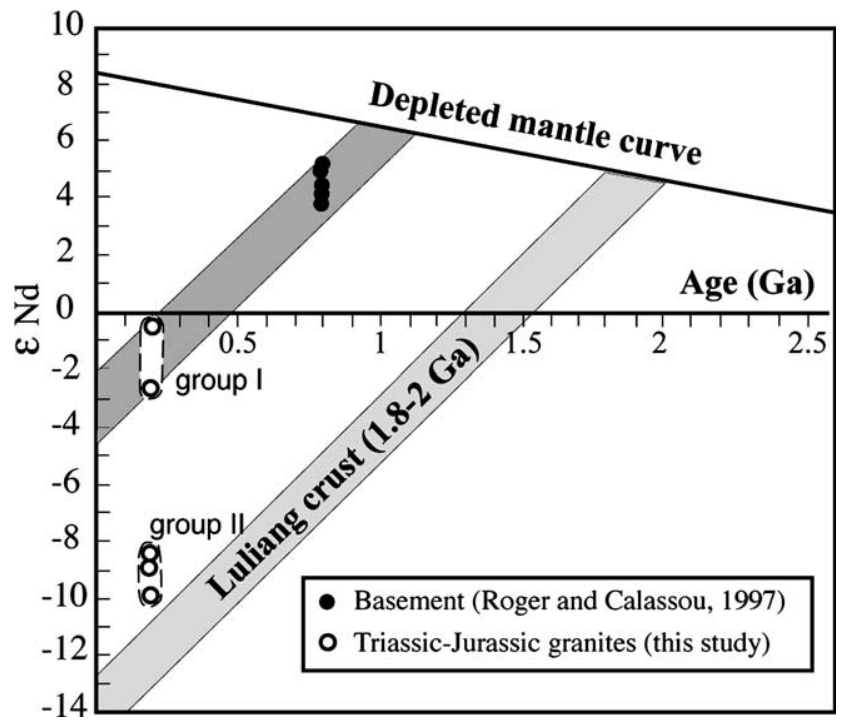

Fig. 7. $\epsilon \mathrm{Nd}$ versus age diagram. The $\epsilon \mathrm{Nd}$ values for the two groups of granite studied are compared with those of basement rocks and two crustal evolutionary models: extraction from the depleted mantle at $0.9-1.1$ or 1.8-2 Ga ago (Luliang crust). 
Table 5

Differences between group I and II of granites

\begin{tabular}{|c|c|c|}
\hline Samples & Group I CDU 26, DB 35 & Group II CDU 114, CDU 119, CDU 57 \\
\hline Rock type & Amphibole granite & Mica (Bt and/or Mus) granite \\
\hline Accessory minerals & Zircon, apatite, titanite & Zircon, monazite \\
\hline Zircon type after Pupin (1980) & Mostly P3, P4 and P5 & Mostly S9, S4, S5, P1, G \\
\hline $\mathrm{Pb}$ concentration of $\mathrm{K}$-feldspar (ppm) & 15 and 19 & $26-37$ \\
\hline${ }^{206} \mathrm{~Pb} /{ }^{204} \mathrm{~Pb}$ & 18.38 and 18.43 & $18.59-18.63$ \\
\hline${ }^{207} \mathrm{~Pb} /{ }^{204} \mathrm{~Pb}$ & 15.66 and 15.74 & $15.78-15.80$ \\
\hline Nd concentration of whole rock (ppm) & 37 and 54 & $7-14$ \\
\hline Sm concentration of whole rock (ppm) & 6 and 10 & $2-3$ \\
\hline${ }^{147} \mathrm{Sm} /{ }^{144} \mathrm{Nd}$ & 0.08 and 0.10 & $0.12-0.14$ \\
\hline$\epsilon \mathrm{Nd}_{\mathrm{i}}($ with $i=200 \mathrm{Ma})$ & 0.25 and $(-2.6)$ & $(-8.4)-(-10)$ \\
\hline$T_{\mathrm{DM}}(\mathrm{Ma})$ & 672 and 896 & $1612-1793$ \\
\hline Sr concentration of whole rock (ppm) & 518 and 705 & $27-116$ \\
\hline $\mathrm{Rb}$ concentration of whole rock (ppm) & 72 and 171 & $127-425$ \\
\hline$\left({ }^{87} \mathrm{Sr} /{ }^{86} \mathrm{Sr}\right)_{i}($ with $i=200 \mathrm{Ma})$ & 0.704 and 0.707 & $0.710-0.712$ \\
\hline Emplacement age & $197 \pm 6$ and $195 \pm 6 \mathrm{Ma}$ & $188 \pm 2$ and $153 \pm 3 \mathrm{Ma}$ \\
\hline
\end{tabular}

(Harrison and Armstrong, 1978; Purdy and Jäger, 1976) and from 450 to $500{ }^{\circ} \mathrm{C}$ (Purdy and Jäger, 1976; Cliff, 1985), respectively. The $\mathrm{Rb}-\mathrm{Sr}$ closure temperature for amphibole is unknown but is usually assumed to be close to that of ${ }^{39} \mathrm{Ar} /{ }^{40} \mathrm{Ar}$ age of amphibole $\left(\approx 500{ }^{\circ} \mathrm{C}\right.$; Harrison, 1981 ; Berger and York, 1981). Our $\mathrm{Rb}-\mathrm{Sr}$ data span from $153 \pm 7$ to $78.5 \pm 4 \mathrm{Ma}$ (Fig. 8). These data appear coherent with the $\mathrm{K}-\mathrm{Ar}$ ages measured in this area (Fig. 2(a)-(c)) (Geological Map of Qinghai-Xizang Plateau and Adjacent Area, 1981).

At lower temperature, fission track measurements on zircon and apatite indicate a rapid Tertiary cooling of the Ma Nai granite (Fig. 8) (Xu and Kamp, 2000). In the Songpan Garze area, post $25 \mathrm{Ma}$ rapid cooling and exhumation is documented by several ${ }^{39} \mathrm{Ar} /{ }^{40} \mathrm{Ar}$, fission track and U/He studies (Kirby et al., 2002; Xu and Kamp, 2000; Arne et al., 1997). These studies show that the maximum of Tertiary cooling is along the Xianshui He fault (Xu and Kamp, 2000) and the Long Men Shan belt (Kirby et al., 2002). Farther up in the plateau interior, where our samples are located, these studies imply that temperatures below $350{ }^{\circ} \mathrm{C}$ and very slow cooling rates where maintained since the Jurassic until at least $50 \mathrm{Ma}$.

Most data from the Ma Nai, Rilonguan and Markam granites appear to define a simple cooling history with rapid cooling from $\sim 200$ to $\sim 150 \mathrm{Ma}$ followed by very slow cooling until $\sim 25 \mathrm{Ma}$ (Fig. 8). Emplacement of the porphyritic facies at $\sim 153 \mathrm{Ma}$ would then have been followed by rapid cooling (Fig. 8). However, the amphibole $\mathrm{Rb} / \mathrm{Sr}$ age are significantly younger than the CDU114 biotite age (Fig. 8), we thus propose three hypothesis to interpret those data.

(1) Most $\mathrm{Rb}-\mathrm{Sr}$ data effectively correspond to cooling ages, but two distinct cooling histories have to be distinguished: one for the group I granites (Rilonguan and Ma Nai) and another one for the group II granite (Markam).
Group I cooling history is built from the DB35 and CDU26 zircon, DB35 titanite, CDU26 apatite $\mathrm{U} / \mathrm{Pb}$ ages and DB35 and CDU26 amphiboles Rb-Sr ages (curve 1, Fig. 8). After the granites were emplaced, between $\sim 200$ and $180 \mathrm{Ma}$ relatively rapid cooling $\left(\sim 20{ }^{\circ} \mathrm{C} / \mathrm{Ma}\right)$ took place (curve 1a, Fig. 8). This initial cooling was followed by a long period of very slow cooling $\left(0-3{ }^{\circ} \mathrm{C} / \mathrm{Ma}\right)$ which would reflect a very slow denudation rate $(\leq 0.1 \mathrm{~mm} / \mathrm{yr})$. During very slow cooling, significant age differences, such as that observed between CDU26 and DB35 amphibole $\mathrm{Rb}-\mathrm{Sr}$ ages, can easily result from small differences in closure temperature or minor local thermal perturbation. In the group II Markam granite CDU 114 monazite $\mathrm{U} / \mathrm{Pb}$ age is compatible with the initial cooling observed in the other granites (curve 1a, Fig. 8). However, a muscovite 40Ar/39Ar age (Arne et al., 1997), CDU114 biotite $\mathrm{Rb}-\mathrm{Sr}$ and the K/Ar biotite ages (Geological Map of Qinghai-Xizang Plateau and Adjacent Area, 1981) suggest that the Markam granite (group II) was significantly colder than group I granites during the Cretaceous (curve 2b, Fig. 8). All together, the cooling history of the Songpan-Garzê would thus have been

Table 6

Compilation of $\mathrm{U}-\mathrm{Pb}$ closure temperatures from different minerals used in geochronology

\begin{tabular}{lll}
\hline U-Pb system & $T\left({ }^{\circ} \mathrm{C}\right)$ closure & References \\
\hline Zircon & $\geq 800$ & $(1),(2),(3),(4)$ \\
Monazite & $650-750$ & $(5),(6),(7)$ \\
Titanite & $500-700$ & $(1),(8),(9),(10),(11)$ \\
Apatite & $500-600$ & $(12),(13),(14),(15)$ \\
\hline
\end{tabular}

(1): Pidgeon and Aftalion, 1978, (2): Mezger, 1990, (3): Lee et al., 1997, (4): Dah1, 1997, (5): Parrish, 1988, (6): Copeland et al., 1988, (7): Parrish, 1990, (8): Cliff and Cohen, 1980, (9): Cliff, 1985, (10): Cherniak, 1993, (11): Zhang and Schärer, 1996, (12) Watson et al., 1985, (13): Cherniak et al., 1991, (14): Krogstad and Walker, 1994, (15): Von Blanckenburg, 1992. 


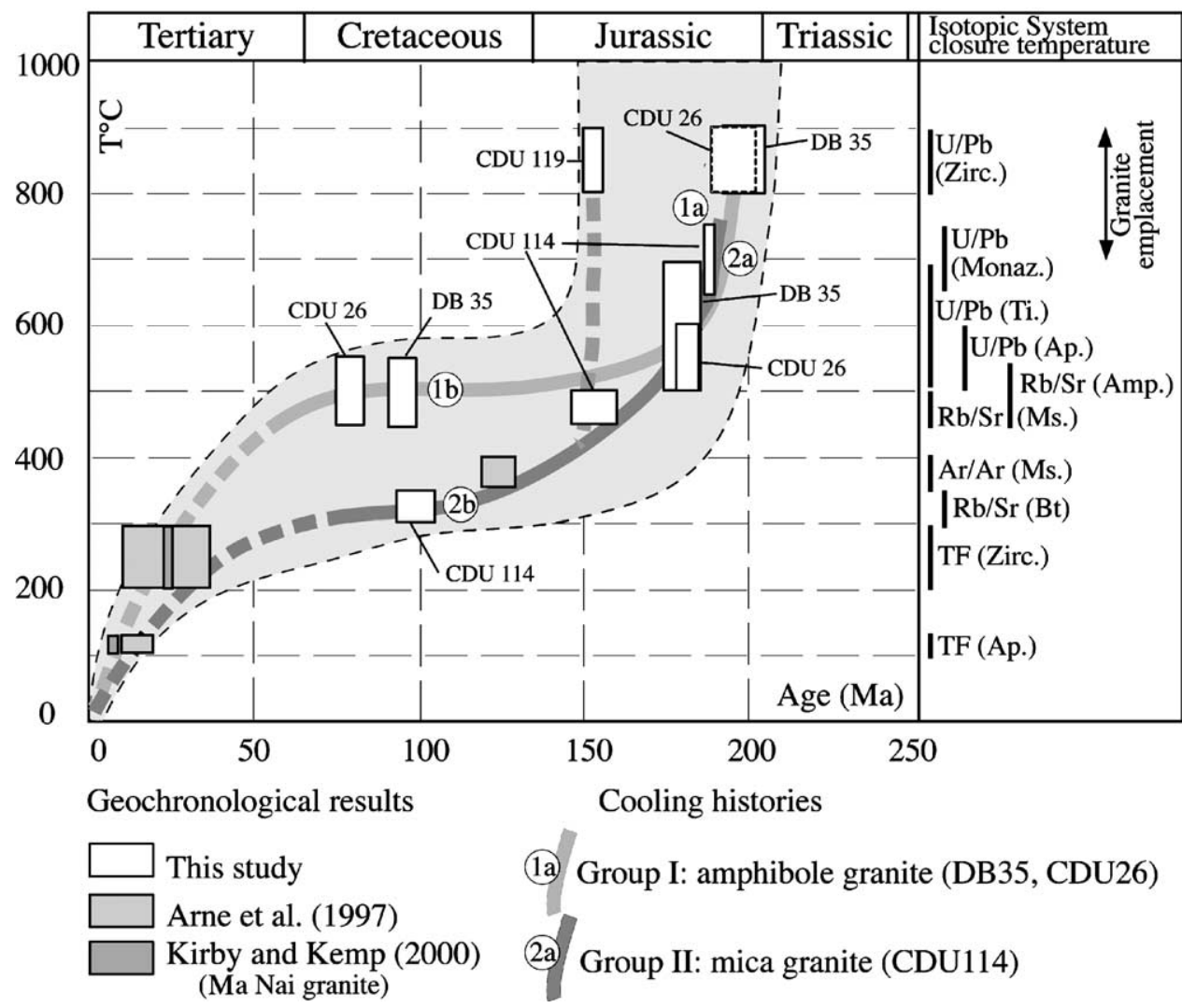

Fig. 8. Cooling history of the Ma Nai (DB 35, Type I), Rilonguan (CDU 26, type I) and Markam granites (CDU 114 and CDU 119 , type II). Closure temperatures used are indicated on the right-side. FT: fission track, Zirc.: zircon, Monaz.: monazite, Ti.: titanite, Ap.: apatite, Amp.: amphibole, Ms.: muscovite, Bt.: biotite.

characterized during the Jurassic by rapid cooling following granite emplacement and by very slow cooling during the Cretaceous (gray area, Fig. 8). The difference in cooling histories between the group I and II granites could be a consequence of their emplacement depth: the Rilonguan and Ma Nai granites were emplaced near the décollement level deeper than the Markam granite. This hypothesis assumes that there has been no post-emplacement re-heating event from the Jurassic to the Tertiary. The final cooling suggested by fission tracks ages could be attributed to the Tertiary uplift and denudation of the Tibetan Plateau (Arne et al., 1997; Xu and Kamp, 2000).

(2) The CDU26 and DB35 Rb-Sr amphibole ages are interpreted as reflecting a regional Late Cretaceous reheating event (Yanshanian event) as suggested by some earlier K/Ar, $\mathrm{Rb} / \mathrm{Sr}$ and ${ }^{40} \mathrm{Ar} /{ }^{39} \mathrm{Ar}$ studies (Xu et al., 1985; Harris et al., 1988a,b; Arne et al., 1997). The temperature reached during this event would not have exceeded $500{ }^{\circ} \mathrm{C}$, because CDU26 and DB35 apatite and titanite $\mathrm{U}-\mathrm{Pb}$ systems were not affected. Such limited temperature increase could result from the deformation caused by Mesozoic collision and accretion of the South Tibet blocks (Lhasa block, etc.) to Eurasia. However, field studies and identification of tectonic features related to this Yanshanian event remain unclear in the Songpan-Garzê area. Furthermore, such regional heating event would be in contradiction with the $\sim 130 \mathrm{Ma}$ fossil fission tracks partial annealing zone preserved away from the Long Men Shan belt and Xianshui He Fault (Xu and Kamp, 2000; Kirby et al., 2002).

(3) A major thermal event has occurred during the Tertiary and the two $\mathrm{Rb} / \mathrm{Sr}$ amphibole data are only intermediate ages without geological significance. They could result from partial resetting of the $\mathrm{Rb}-\mathrm{Sr}$ isotopic system while not resetting the $\mathrm{U}-\mathrm{Pb}$ ones. Such an event could be linked with the Tertiary India-Asia collision, for example, shortening to the north of the Miocene Xianshui He strike-slip fault and emplacement of the Konga Shan granite along that fault (Roger et al., 1995), or re-activation of the decollement level. Again this would contradict with the fission tracks data (Xu and Kamp, 2000).

In the absence of any clear evidence for a major regional thermal event in the Tertiary or the Cretaceous we prefer our first hypothesis.

\section{Conclusion}

The syn-kinematic Ma Nai granite DB35 associated with the main Indosinian deformation records a minimum age of $197 \pm 6 \mathrm{Ma}$ which is interpreted as an upper limit for that tectonic event. Jurassic ages (195 \pm 6 and $181 \pm 4 \mathrm{Ma})$ are also yielded by zircons and apatites 
from the undeformed Rilonguan granite (CDU26). The post-orogenic Markam massif probably contains two distinct granites with ages of $188 \pm 2$ (CDU114) and $153 \pm 3 \mathrm{Ma}$, respectively. The Rilonguan and Markam granites cut the folds of the Triassic belt. These results demonstrate that the major deformation and décollement tectonics in the Songpan-Garzê fold belt occurred during the Early Jurassic (Fig. 9).

The geochemical data suggest that syn-kinematic melts (group I granite) probably resulted from partial melting of the basement below the main décollement level. Conditions for partial melting at relatively shallow level $(\sim 20 \mathrm{~km})$ most likely resulted from strong shortening and large thickening of the sedimentary cover above the décollement (cf. England and Thompson, 1984) (Fig. 9(b)). During deformation, the temperature increase could have been promoted by shear heating along the décollement (cf. Molnar and England, 1990; Leloup et al., 1999). After the deformation, group II granites cristallization appears to have lasted from $\sim 50 \mathrm{Ma}$ until $150 \mathrm{Ma}$, the age of the porphyritic Markam granite (Fig. 9). This suggests that, at least locally, conditions compatible with partial fusion of the sedimentary cover persited for a long time span. This is in agreement with the thermal
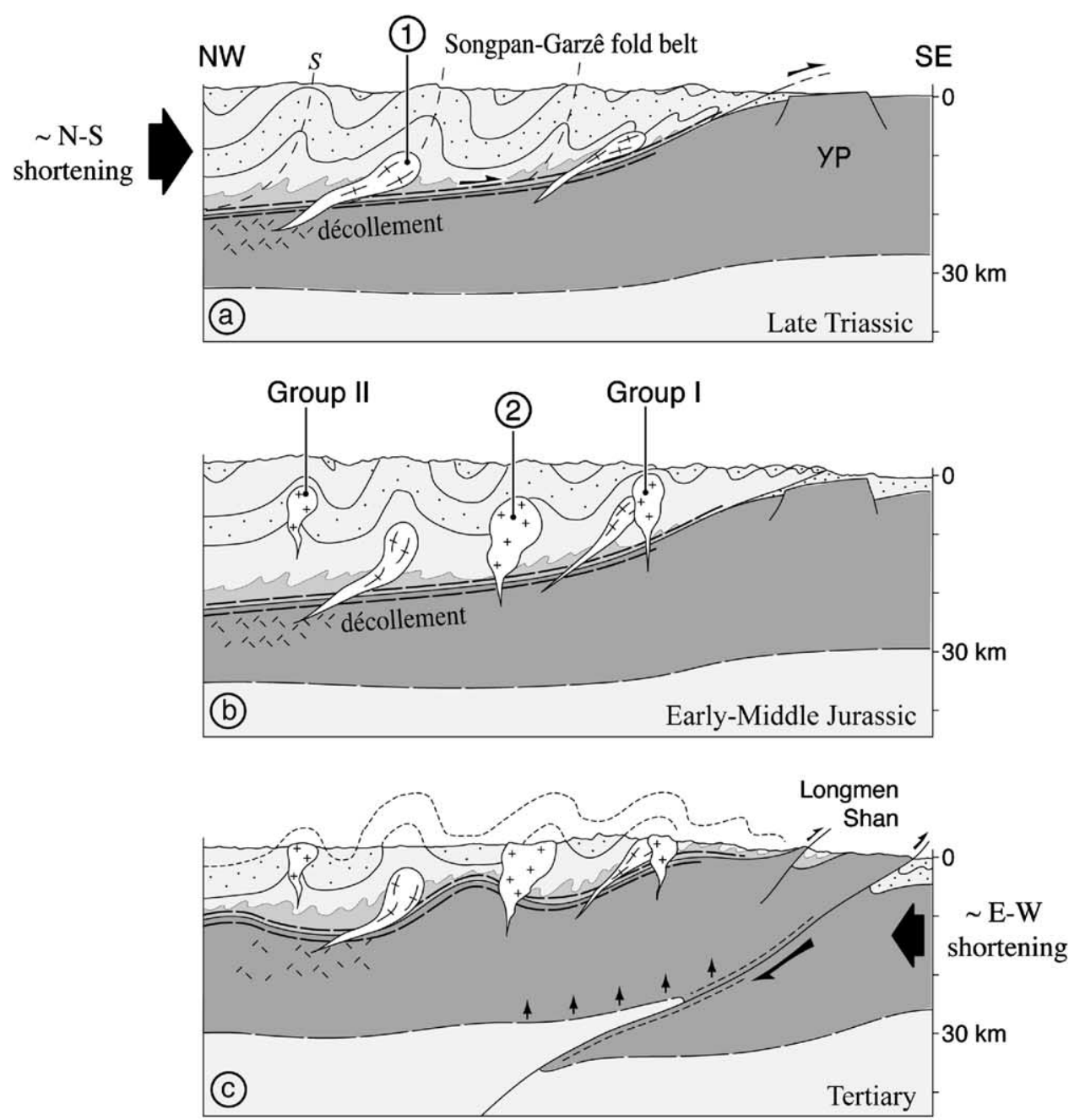

Granitoids

Migmatites

Triassic - Early Jurassic

Paleozoic

Undifferenciated basement

Fig. 9. Sketch showing tectonic evolution of the SE Songpan-Garzê area through time. (a) Indosinian stage until the Early Jurassic ( $\approx 195$ Ma). Large-scale décollement with syn-kinematic granite emplacement (i.e. Ma Nai granite) and strong folding and thickening of the overlying sedimentary series. (b) Post Indosinian stage (Jurassic: $\approx 195-150 \mathrm{Ma}$ ). Emplacements of post-orogenic granites crosscut the Indosinian folds (i.e. Rilonguan and Markam granites). (c) Tertiary intra-continental shortening and associated uplift-erosion. $\mathrm{S}=$ Schistosity associated to the main tectonic event, YP $=$ Yangtze Plate. 
relaxation time of a strongly thickened crust (England and Thompson, 1984). The small amount of erosion and exhumation occurring in the wide Songpan-Garzê fold belt during the Mesozoic period (Fig. 9) did not allow the crust to thin and cool. Regionally, the Songpan-Garzê décollement was probably comparable with those from the Qinling and Dabie Shan, located far to the northeast (Hsü et al., 1987; Mattauer et al., 1991; Huang and Wu, 1992). Triassic ages have also been recorded in those orogens and the tectonic style is similar: the Paleozoic and Triassic cover sequence was thrusted onto the Yangtze basement with a shear sense indicating top to the South displacement. Such movement was probably the result of closure of the Songpan-Garzê ocean that represented the Northern part of the Paleo-Tethys along a North dipping subduction zone between North China and South China. Our data do not show any clear evidence for a 'Yanshan' (Late Jurassic-Cretaceous) magmatic or tectonic event.

No Tertiary ages have been obtained suggesting that the studied granites were little or not at all affected by the effects of India-Asia collision. They were not reheated to temperatures higher than $\sim 350{ }^{\circ} \mathrm{C}$. However, final exhumation and cooling of the Songpan-Garzê belt occurred in the Tertiary (Fig. 8) (Xu and Kamp, 2000; Kirby et al., 2002). Away from the Longmen Shan belt, the exhumation has been limited, as suggested by the few metamorphic terranes exhumed and the preservation of old fission track ages, but relief is high $(\sim 4000 \mathrm{~m}$ on average in this part of the Tibetan Plateau). The deeper terranes exhumed are located in the Danba anticline and in the hanging wall of the Longmen Shan thrust belt (Fig. 1). In the study area, it seems that Tertiary deformations are restricted to strike-slip faulting along the Xianshui He fault zone (Roger et al., 1995), and exhumation of the Triassic-Lower Jurassic décollement level in the hanging wall of the Longmen Shan thrust belt (Fig. 9(c)).

\section{Acknowledgements}

This work was a cooperative study between the Chinese Ministry of Geology and Mineral Resources, the Institute of Geology in Beijing, and the Institute of Geological and Mineral Resources in Chengdu and the CNRS-INSU (France). The authors wish to thank J.P. Respaut for helpful discussions of the manuscript, Mr Li Ting Dong, Xiao Xucheng and G. Aubert for their help, the team of Chinese geologists (Hao Ziwen, Hou Liwei) for organisation and successful operation of the missions and A.C. Morillon for her help in the drafting of some Figures. This work was supported by a D.B.T. program 'Dynamique et Bilan de la Terre', thème 5 .

\section{Appendix A}

\section{Analytical procedure}

Each sample was crushed and split into two parts: one for mineral separation and the other for whole rock analyses. The rocks were powdered in a SPEX tungsten carbide crusher. Typological analyses (Pupin, 1980) are done on 100 randomly selected euhedral to subhedral zircon crystals of each population. The mean points for each population were computed following the method of Pupin (1980). Zircon typology describes the relative development of one or two prismatic ((100) and (110)) and one or more pyramidal crystal faces (mainly (101) and (211)). This appears to reflect the crystallization conditions such as melt composition (the aliminium/alkali antagonism) and crystallization temperature and has been used as a genetic tool (Pupin, 1980).

Mineral separates, handpicked under a binocular microscope, were nearly $99 \%$ pure. The selection was based on criteria such as morphology, transparency, colour, cracking and frequency of inclusions. For zircon $\mathrm{U}-\mathrm{Pb}$ analysis, the zircons were digested in $48 \% \mathrm{HF}$ in Teflon microbombs at $200{ }^{\circ} \mathrm{C}$ for about a week for fractions and 2 days for single grains. Titanites and monazites were digested in microbombs in a mixed solution of $\mathrm{HF}(48 \%)-\mathrm{HNO}_{3}(13 \mathrm{~N})$ and $\mathrm{HCl}(6 \mathrm{~N})$ at $195{ }^{\circ} \mathrm{C}$ for 3-4 days. Apatite was dissolved in PFA Teflon beaker in $\mathrm{HCl}(6 \mathrm{~N})$ on a hot plate. An aliquot of the dissolved sample was spiked with a combined ${ }^{208} \mathrm{~Pb} /{ }^{235} \mathrm{U}$ tracer in order to calculate uranium and lead contents. Separation of both elements was carried out on AG1X8 ion exchange resin microcolumns (Krogh, 1973; Manhes, 1982). U was loaded on a W single filament with a $\mathrm{TaCl}_{5}$ activator while $\mathrm{Pb}$ was loaded on a Re single filament with silica-gel and $\mathrm{H}_{3} \mathrm{PO}_{4}$ emission activator. Isotopic ratios were measured by a solid-source CAMECA TSN 206 mass spectrometer with an automatic data acquisition system. Decay constants used for ${ }^{238} \mathrm{U}$ and ${ }^{235} \mathrm{U}$ were $0.155125 \times 10^{-9}$ and $0.98485 \times 10^{-9}$ year $^{-1}$, respectively (Steiger and Jäger, 1977). Successive analyses of a NBS983 standard yielded a mean fractionation value of $1.015 \pm 0.16 \%$ per atomic mass unit. The total Pb-blank was around $50 \mathrm{pg}$. The isotope data were obtained on a CAMECA TSN 206 except for single grains (VG Sector). The measured ratios were processed using a numerical simulation program developed by Briqueu and de la Boisse (1990). The isotopic composition of the initial common $\mathrm{Pb}$ was determined on $\mathrm{K}$ feldspars from the same rock sample (Table 3).

$\mathrm{Rb}-\mathrm{Sr}$ data were obtained using techniques described in Birck and Allegre, 1978. After dissolution, $\mathrm{Rb}$ and $\mathrm{Sr}$ are extracted on cation exchange resins. $\mathrm{Ca}-\mathrm{Sr}$ were separated using ammonium citrate as complexing agent. The total procedural blank was less than $20 \mathrm{pg}$ for $\mathrm{Sr}$ and $1 \mathrm{pg}$ for $\mathrm{Rb}$. In all cases, the blank was considered negligible. The isotope 
data were obtained on a VG sector mass spectrometer, while the ${ }^{87} \mathrm{Rb} /{ }^{85} \mathrm{Rb}$ ratio were measured on a CAMECA TSN 206. Sr is loaded with a Ta activator on a single $\mathrm{W}$ filament. $\mathrm{Sr}$ ratios were normalized to ${ }^{86} \mathrm{Sr} /{ }^{88} \mathrm{Sr}=0.1194$. $\mathrm{Rb}$ was loaded on a single W filament. During the course of this study, NBS 987 standards were regularly run. Mean measured values are $0.710248 \pm 12(2 \sigma)$, on 100 runs. The $\mathrm{Rb}, \mathrm{Sr}, \mathrm{U}$ and $\mathrm{Pb}$ concentrations were obtained by isotopic dilution techniques.

\section{References}

Allen, C.R., Luo, Z., Qian, H., Wen, Y., Zhou, H., Huang, W., 1991. Field study of a highly active fault zone: the Xian Shui He fault of southwestern China. Geological Society of America Bulletin 103, 1178-1199.

Arne, D., Worley, B., Wilson, C.J.L., Chen, S.F., Foster, D., Luo, Z.L., Liu, S., Dirks, P., 1997. Differential exhumation in response to episodic thrusting along the eastern margin of the Tibetan Plateau. Tectonophysics 280, 239-256.

Berger, G.W., York, D., 1981. Geothermometry from 40Ar/39Ar dating experiments. Geochemica Cosmochemica Acta 45, 795-811.

Birck, J.L., Allegre, C.J., 1978. Chronology and chemical history of the parent body of basaltic achondrites studies by the ${ }^{87} \mathrm{Sr} /{ }^{86} \mathrm{Sr}$ method. Earth and Planetary Science Letters 39, 37-51.

Briqueu, L., De La Boisse, H., 1990. U-Pb geochronology: systematic development of mixing equations and application of Monte Carlo numerical simulation to the error propagation in the Concordia diagram. Chemical Geology 88, 69-83.

Bruguier, O., Lancelot, J.R., Malavieille, J., 1997. U-Pb dating on single detrital zircon grains from the Triassic Songpan-Ganze flysch (central China): provenance and tectonic correlations. Earth and Planetary Science Letters 152, 217-231.

Burchfield, B.C., Chen, Z., Liu, Y., Royden, L.H., 1995. Tectonics of the Longmen Shan and adjacent regions, Central china. International Geology Review 37, 661-735.

Calassou, S., 1994. Etude tectonique d'une chaine de décollement: A) tectonique Triasique et tertiaire de la chaine de Songpan-Garzê. B) géométrie et cinématique des déformations dans les prismes d'accrétion sédimentaire: modélisation analogique. Thèse, Univ. Montpellier II, $400 \mathrm{pp}$

Chen, S.F., Wilson, C.J.L., 1996. Emplacement of the Longmen Shan Thrust-Nappe Belt along the eastern margin of the Tibetan Plateau. Journal of Structural Geology 18, 413-440.

Chen, S.F., Wilson, C.J.L., Worley, B.A., 1995. Tectonic transition from the Songpan-Garzê Fold Belt to the Sichuan Basin, south-western China. Basin Research 7, 235-253.

Cherniak, D.J., 1993. Lead diffusion in titanite and preliminary results on the effects of radiation damage on $\mathrm{Pb}$ transport. Chemical Geology 110 , $177-194$.

Cherniak, D.J., Lanford, W.A., Ryerson, F.J., 1991. Lead diffusion in apatite and zircon using ion implantation and Rutherford backscattering techniques. Geochimica Cosmochimica Acta 55, 1663-1673.

Cliff, R.A., 1985. Isotopic dating in metamorphic belts. Journal of the Geological Society of London 142, 97-110.

Cliff, R.A., Cohen, A., 1980. Uranium lead isotope studies systematics in a regionally metamorphosed tonalite from the Eastern Alps. Earth and Planetary Science Letters 50, 211-218.

Copeland, P., Parrish, R.R., Harrison, T.M., 1988. Identification of inherited $\mathrm{Pb}$ in monazite and its implications for $\mathrm{U}-\mathrm{Pb}$ systematics. Nature 333, 760-763.

Dahl, P.S., 1997. A crystal-chemical basis for $\mathrm{Pb}$ retention and fission-track annealing systematics in U-bearing minerals, with implications for geochronology. Earth and Planetary Science Letters 150, 277-290.
DePaolo, D.J., 1981. Neodymiun isotopes in the Colorado Front range and crust-mantle evolution in the Paleozoic. Nature 291, 193-196.

Dirks, P.H.G., Wilson, C.J.L., Chen, S., Luo, Z.L., Liu, S., 1994. Tectonic evolution of the NE margin of the Tibetan Plateau; evidence from the central Longmen Mountains, Sichuan Province, China. Journal of Southern Asian Earth Sciences 9 (1/2), 181-192.

Dodson, M.H., 1973. Closed temperature in cooling geochronological and petrological systems. Contributions to Mineralogy and Petrology 40, 259-274.

England, P.C., Thompson, A.B., 1984. Pressure-temperature-time paths of regional metamorphism I. Heat transfer during the evolution of regions of thickened continental crust. Journal of Petrology 25, 894-928.

Enkin, R., Yang, Z., Chen, Y., Courtillot, V., 1992. Paleomagnetic constraints on the geodynamic history of the major blocks of China from the Permian to the present. Journal of Geophysical Research 97, 13953-13989.

Geological Map of Sichuan Province (1/1,000,000), Inst. Geol. Min. Res. Chengdu, 1981

Geological Map of Qinghai-Xizang (Tibet) Plateau and adjacent Areas (1/ 1,500,000) and Expl. Note, Inst. Geol. Min. Res. Chengdu, 1991

Harris, N.B.W., Xu, R., Lewis, C.L., Jin, C.W., 1988a. Plutonic rocks of the 1985 Tibet Geotraverse, Lhasa to Golmud. Philosophical Transactions of the Royal Society of London 327, 145-168.

Harris, N.B.W., Xu, R., Lewis, C.L., Hawhesworth, C.J., Zhang, Y.Q., 1988b. Isotope geochemistry of the 1985 Tibet Geotraverse, Lhasa to Golmud. Philosophical Transactions of the Royal Society of London 327, 263-285.

Harrison, T.M., 1981. Diffusion of ${ }^{40} \mathrm{Ar}$ in hornblende. Contributions of Mineralogy and Petrology 78, 324-331.

Harrison, T.M., Armstrong, R.L., 1978. Thermal models and cooling histories from fission-track, $\mathrm{K}-\mathrm{Ar}, \mathrm{Rb}-\mathrm{Sr}$, and $\mathrm{U}-\mathrm{Pb}$ mineral dates, Northern Coast Pluton Complex, British Colombia (abstr). Fourth International Conference on Geochronology Cosmochronology Isotope Geology.

Hsü, K.J., Qingchen, W., Li, J., Zhou, D., Sun, S., 1987. Tectonic evolution of Qinling Mountains, China. Eclogae Geologicae Helvetiae 80 (3), $735-752$

Huang, W., Wu, Z.W., 1992. Evolution of the Qinling orogenic belt. Tectonics 11, 371-380.

Kirby, E., Reiners, P.W., Krol, M.A., Whipple, K.X., Hodges, K.V., Farley, K.A., Tang, W., Chen, Z., 2002. Late Cenozoic evolution of the eastern margin of the Tibetan Plateau: inferences from 40Ar/39Ar and (U-Th)/ He thermochronology. Tectonics 21, 1.1-1.20.

Krogh, T.E., 1973. A loss contamination decomposition of zircon and extraction of $\mathrm{U}$ and $\mathrm{Pb}$ for isotopic age determination. Geochimica Cosmochimica Acta 37, 485-494.

Krogstad, E.J., Walker, R., 1994. High closure temperatures of the U-Pb system in large apatites from the Tin Mountain pegmatite, Black Hill, South Dakota, USA. Geochimica Cosmochimica Acta 18, 3845-3853.

Lee, J.K.W., Williams, I.S., Ellis, D.J., 1997. Pb, U and Th diffusion in natural zircon. Nature 390, 159-161.

Leloup, Ph.H., Ricard, Y., Battaglia, J., Lacassin, R., 1999. Shear heating in continental strike-slip shear zones: model and field examples. Geophysical Journal International 136, 19-40.

Liu, B.T., 1984. The geological tectonic character of fold system from Bayanhar to Kunlun and its evolution. Contributions to the Geology of the Qinghai-xizang (Tibet Plateau) 15, 101-111.

Luo, Z.L., Long, X.M., 1992. The uplifting of the Longmen Shan orogenic zone and the subsidence of the West Sichuan Foreland Basin. Acta Geology Sichuan 12, 1-17.

Malavieille, J., Mattauer, M., Lancelot, J., Calassou, S., Xu, Z., Hao, Z., 1991. Large scale décollement in the Indo-Sinian (Triassic) fold belt of Eastern Tibet. Terra Nova Abstracts 3, 258.

Manhes, K.G., 1982. Développement de l'ensemble chronométrique U$\mathrm{Th}-\mathrm{Pb}$. Contribution à la géochronologie initiale du système solaire, Thèse, Paris VII, 225 pp 
Mattauer, M., Matte, Ph., Maluski, H., Xu, Z., Wen, Z.Q., Ming, W.Y., 1991. La limite Chine du Nord-Chine du Sud au Paléozoïque et au Trias. Nouvellles données structurales et radiométriques dans le massif du Dabie-Shan chaîne des Qinling). Comptes Rendus de l'Académie des Sciences Paris 312, 1227-1233.

Mattauer, M., Malavieille, J., Calassou, S., Lancelot, J., Roger, F., Hao, Z., Xu, Z., Hou, L., 1992. La chaîne triasique de Songpan-Garzê (Ouest Sechuan et Est Tibet): une chaîne de plissement-décollement sur marge passive. Comptes Rendus de l'Académie des Sciences Paris 314, 619-626.

Mattinson, J.M., 1978. Age, origin and thermal history of some plutonic rocks from the Salinian block of California. Contributions to Mineralology and Petrolology 67, 233-245.

Mezger, K., 1990. Geochronology in granulites. In: Vielzeuf, D., Vidal, Ph. (Eds.), Granulites and Crustal Evolution, Kluwer, pp. 451-470.

Molnar, P., England, P., 1990. Temperature, heat flux, and frictional stress near major thrust faults. Journal of Geophysical Research 95 , 4833-4856.

Nie, S., Yin, A., Rowley, D.B., Jin, Y., 1994. Exhumation of the Dabie Shan ultra-high-pressure rocks and accumulation of the Songpan-Ganzi flysh sequence, central China. Geology 22, 999-1002.

Parrish, R.R., 1990. U-Pb dating of the monazite and its applications to geological problems. Canadian Journal of the Earth Sciences 27, $1431-1454$.

Pidgeon, R.T., Aftalion, M., 1978. Cognetic and inherited zircon U-Pb systems in granites: Paleozoic granites of Scotland and England. Geology Journal Special Issue 10, 183-220.

Pupin, J.P., 1980. Zircon and granite petrology. Contributions to Mineralogy and Petrology 73, 207-220.

Purdy, J.W., Jäger, E., 1976. K-Ar ages on rockforming minerals from the Central Alps. Memorie degli Istituti di Geologia e Minerologia di Padova, 1-321.

Rao, R.B., Xu, J.F., 1987. The Triassic System of the Qinghai-Xizang Plateau, Geological Publishing House, Beijing, pp. 201-239.

Roger, F., 1994. Datation et traçage des granitoïdes associés à la chaine de Songpan-Garzê (Ouest Sichuan, Chine) par les méthodes: U-Pb, Rb$\mathrm{Sr}$ et $\mathrm{Sm}-\mathrm{Nd}$. Thèse, Univ. Montpellier II, $207 \mathrm{pp}$

Roger, F., Calassou, S., 1997. Géochronologie U-Pb sur zircons et géochimie $(\mathrm{Pb}, \mathrm{Sr}$ et $\mathrm{Nd}$ ) du socle de la chaîne de Songpan-Garze (Chine). Comptes Rendus de l'Académie des Sciences Paris 324, 819-826.

Roger, F., Calassou, S., Lancelot, J., Malavieille, J., Mattauer, M., Xu, Z., Hao, Z., Hou, L., 1995. Miocene emplacement and deformation of the Konga Shan granite (Xianshui He fault zone, west Sichuan, China): geodynamical implications. Earth and Planetary Science Letters 130, $201-216$.

Roger F., Arnaud, N., Gilder, S., Tapponnier, P., Jolivet, M., Brunel, M., Malavieille, J., Xu, Z., 2003. Geochronological and geochemical constraints on Mesozoic suturing in East Central Tibet. Tectonics, in press.
Schärer, U., Kornprobst, J., Beslier, M.O., Boillot, G., Girardeau, J., 1995. Gabbro and related rock emplacement beneath rifting continental crust: $\mathrm{U}-\mathrm{Pb}$ geochronological and geochemical constraints for Galicia passive margin (Spain). Earth and Planetary Science Letters 130, $187-200$.

Sengör, A.M.C., 1985. Tectonic subdivisions and evolution of Asia. Bulletin of Technical University of Istanbul 46, 355-435.

Silver, L.T., Deutsch, S., 1961. Uranium lead method on zircons. Proceedings of New York Academy of Science 91, 279-283.

Stacey, J.S., Kramers, J.D., 1975. Approximation of terrestrial lead isotope evolution by a two stage model. Earth and Planetary Science Letters 26, 207-221.

Steiger, R.H., Jäger, E., 1977. Subcommission on geochronology: convention on the use of decay constants in geo- and cosmochronology. Earth and Planetary Science Letters 36, 359-362.

Von Blanckenburg, F., 1992. Combined high-precision chronometry and geochemical tracing using accessory minerals: applied to the centralalpine Bergell intrusion (Central Europe). Chemical Geology 100, 19-40.

Watson, E.B., Harrison, T.M., Ryerson, F.J., 1985. Diffusion of Sm, Sr, and $\mathrm{Pb}$ in fluorapatite. Geochimica Cosmochimica Acta 49, 1813-1823.

$\mathrm{Xu}$, G., Kamp, P.J.J., 2000. Tectonics and denudation adjacent to the Xianshuihe fault, eastern Tibetan Plateau: constraints from fission track thermochronology. Journal of Geophysical Research 105, $19231-19251$

Xu, R.H., Schärer, U., Allègre, C.J., 1985. Magmatism and metamorphism in the Lhasa block (Tibet): a geochronological study. Journal of Geology 93, 41-57.

Xu, Z., Hou, L., Wang, Z., 1992. Orogenic Processes of the SongpanGarzê Orogenic Belt of China, Geological Publishing House, Beijing, 190 pp..

Yuan, H.H., Zhang, Z.L., Zhang, P., 1991. The uplifting and cooling histories of the Laojungou granite in the western margin of the central section of the Longmen Mountains. Journal of Chengdu College Geology 18, 17-22.

Zartman, R.E., Doe, B.R., 1981. Plumbotectonics: the model. Tectonophysics $75,135-162$.

Zhang, L.S., Schärer, U., 1996. Inherited $\mathrm{Pb}$ components in magnatic titanite and their consequence for the interpretation of $\mathrm{U}-\mathrm{Pb}$ ages. Earth and Planetary Science Letters 138, 57-65.

Zhang, Z.H., Liou, J.G., Coleman, R.G., 1984. An outline of the plate tectonics of China. Geological Society of American Bulletin 95, 295-312.

Zhang, Y., Luo, Y., Yang, C., 1990. Panxi Rift and its Geodynamics, Geological Publishing House, Beijing, 415 pp.

Zou, D.B., Chen, L.K., Rao, R.B., Chen, Y.M., 1984. On the Triassic turbidite in the southern Bayanhar Mountain region. Contributions to the Geology of the Qinghai-Xizang (Tibet) Plateau 15, 27-39. 